\section{School counselors' opinions, knowledge and competencies on substance addiction}

\section{Okul psikolojik danışmanlarının madde bağımlılığ1 konusundaki görüş, bilgi ve yeterlikleri}

\author{
Evrim Çetinkaya Yıldız ${ }^{1}$
}

\begin{abstract}
In this study, school counselors' opinions, knowledge and competencies on substance addiction were investigated. Three hundred and forty counselors participated in the study. Findings showed that, counselors consider substance addiction as a problem in Turkey. It was found out that the participants' level of knowledge about how to communicate with addicted students and their parents is relatively higher than their level of knowledge about substance abuse and addiction treatment. In addition, the findings indicated that participants considered themselves as more competent on implementing preventive studies, identifying addicted students, and working with cigarette addiction. However, they found themselves less competent in working with substance addiction. Lastly, the results revealed that school counselors with professional experience between six to ten years have been found to report significantly higher levels of knowledge and competence in some of items than school counselors with fewer and more seniority.
\end{abstract}

Keywords: Substance addiction, school counselor, competency.

(Extended English summary is at the end of this document)

\section{Özet}

Bu çalışmada okul psikolojik danışmanlarının madde bağımlılığ1 konusundaki görüşleri, bilgileri ve yeterlikleri araştırllmıştır. Araştırmaya üç yüz kırk psikolojik danışman katılmıştır. Bulgular psikolojik danışmanların Türkiye'de madde bağımlilığını bir sorun olarak gördüklerini ortaya koymuştur. Psikolojik danışmanların madde bağımlılığı olan öğrencilere ve velilerine nasıl yaklaşılması gerektiği ile ilgili bilgi düzeylerinin madde bağımlılı̆̆1 ve bağımlılık tedavisi ile ilgili bilgi düzeylerinden daha iyi olduğu tespit edilmiştir. Psikolojik danışmanların koruyucu önleyici çalışmalar yapma, bağıml öğrencileri tespit etme ve sigara bağımlısı öğrencilerle çalışma konularında kendilerini daha yeterli gördükleri, ancak uyuşturucu madde ve alkol bağımlilı̆̆ ile ilgili konularda çalışma konusunda kendilerini daha az yeterli gördükleri belirlenmiştir. Son olarak, alt1 ile on y1l arasinda kıdemi olan psikolojik danışmanların madde bağımlılı̆̆ı ile ilgili rapor ettikleri bazı bilgi ve yeterliklerinin daha az ve daha fazla kıdemli meslektaşlarının rapor ettikleri bilgi ve yeterlik düzeylerinden anlamlı derecede daha yüksek olduğu ortaya çımışstır.

Anahtar Kelimeler: Madde bağımlılı̆̆ı, okul psikolojik danışmanı, yeterlik.

${ }^{1}$ Dr. Öğr. Üyesi, Akdeniz Üniversitesi, Eğitim Fakültesi, Eğitim Bilimleri Bölümü, Rehberlik ve Psikolojik Danışmanlık Ana Bilim Dalı, evrimcetinkaya@gmail.com (D) Orcid ID: 0000-0001-5924-3136 
Çetinkaya Yıldız, E. (2020). Okul psikolojik danıșmanlarının madde bağımlılığı konusundaki görüș, bilgi ve yeterlikleri. Journal of Human Sciences, 17(2), 609-631. doi:10.14687/jhs.v17i2.5926

\section{Giriş}

Madde bağımlılı̆g tüm dünyada olduğu gibi ülkemizde de hem bağımlıları ve ailelerini hem de toplumun genelini etkileyen bir sorundur. Genel popülasyonda madde kullanım oranları 2016 yılında Dünya Uyuşturucu Kullanım Raporunda sunulmuştur. Raporda 15-64 yaş aralığındaki yetişkin nüfusun \%5'inin 2014 yllında en az bir uyuşturucu madde kullandığını ve dünya üzerinde 29 milyon kişinin madde kullanım bozukluğu yaşadığını ortaya koymuştur (Birleşmiş Milletler Dünya Uyuşturucu Raporu, 2016). Türkiye'de ise genel popülasyonda yaşam boyu madde kullanım sıklı̆̆1 Türkiye Uyuşturucu ve Uyuşturucu Bağımlllığı İzleme Merkezinin (TUBIM, 2011) 25 ilde gerçekleştirdiği çalışmada \%2.7 olarak rapor edilmiştir. Türkiye'de madde kullanım sıklığının ne boyutta olduğunu ortaya koymak üzere yürütülmüş çalışmalar mevcuttur. Bu çalş̧maların bazıları bir şehirdeki öğrencilerin bağımlılık durumu ortaya koymuş (Arslan, Terzi, Dabak ve Pekşen, 2012; Doğan, 2001; Erdamar ve Kurupınar, 2014; Karakılınç, 1999), bazıları bağımlılık merkezine başvuran kişilerle yapılmış (Bulut, Savaş, Cansel, Selek, Kap, Yumru ve Vırıt, 2006; Yüncü, Aydın, Çoşkunol, Altıntoprak ve Bayram, 2006), bazıları ise daha büyük ölçekli planlanmış ve farklı illerde yürütülmüştür (Ögel, Çorapçıŏglu, Sır ve ark., 2004). Elde edilen veriler yurtdışındaki araştırmalar ile karşılaştırıldığında, Amerika ve Avrupa'da bulunan ülkelere kıyasla Türkiye'de madde kullanım oranlarının düşük olduğunu fakat madde kullanım sıklı̆ıında bir artış olduğunu göstermektedir (Ögel, Tamar ve Çakmak, 1998).

Okul çă̆ındaki gençlerin madde bağımlılı̆̆ı ise ilgileri en çok endişelendiren konudur. Bu konuda Avrupa'da büyük çaplı araştırmalar yapılmıştır. Avrupa Uyuşturucu Bağımlilı̆̆ İzleme Merkezinin (ESPAD, 2015) anketine göre erkek öğrencilerin \%23’ü, kı öğrencilerin ise \%17'si yaşamları boyunca en az bir kere yasadışı uyuşturucu madde kullandığını rapor etmiştir. Bu çalışmaya Türkiye 2015 yılında katılmamıştır. Katılımc1 ülkelerden Çek Cumhuriyeti’nde \%37, Bulgaristan, Fransa ve Monaco'da \%30-32, Kıbris, Finlandiya ve Makedonya gibi ülkelerde ise \%10'un altında öğrenci yaşamları boyunca en az bir kere uyuşturucu madde denediklerini rapor etmişlerdir. ESPAD araştırmalarına Türkiye 2003 yılında 6 ilden toplanan veri ile katılmıştır. Dolayısıyla bu verileri diğer ülkelerle kıyaslamak ve boylamsal olarak değerlendirmek mümkün değildir. Türkiye'de yürütülmüş olan diğer araştırmalarda ise düzenli aralıklarla veri toplanarak durum tespiti yapılmadığından kullanım eğilimlerini ve bunları etkileyen faktörleri değerlendirmek güçtür (Ünlü ve Evcin, 2010). Ancak, okul çağı gençlerin katılımcı olduğu bazı büyük çaplı araştırmalar Türkiye'de genç nüfusta madde kullanım oranları hakkında fikir vermektedir. Örneğin, 2007 yllında Ankara'da gerçekleştirilen bir çalışmada 13438 öğrenciye ulaşılmıştır. Katılımc1 öğrencilerden \%1.4’ü düzenli olarak, \%1’i ise deneme düzeyinde madde kullandığını belirtmiştir (TUBiM, 2008). Birleşmiş Milletler Uyuşturucu Suç Ofisi (UNODC, 2003) tarafından liseye devam eden öğrencilerin örneklem alındığı bir diğer araştırmada yaşam boyu en az bir kere madde kullanım oranları araştırılmıştır. Bulgular farklı maddeler için kullanım yaygınlığınının şu şekilde olduğunu ortaya koymuştur: Esrar \%5.1, ekstazi \%3.2, uçucu madde $\% 5.2$, sedatif hipnotik ilaçlar $\% 5.4$, eroin $\% 2.8$ ve flunitrazepam $\% 3.1$ olarak rapor edilmiştir. Aynı çalışmada yaşam boyu en az bir kere madde kullanım yaygınlığının farklı şehirlerdeki oranları da araştırılmıştır. Lise öğrencileri arasında en az bir kere esrar kullanım yaygınlığının Adana'da \%3.3, Ankara'da \%2.9, Diyarbakır'da \%5.1, İzmir'de \% 6.1 ve Samsun'da \%3.8 olduğu tespit edilmiştir. Bir diğer çalışmada İstanbul'da lise öğrencilerinin \%44'ünün yaşamları boyunca en az bir kez sigara içtikleri, \%61'inin en az bir kez alkollü içki içtikleri ve \%19’unun en az bir kez sarhoş oldukları bulunmuştur (Alikaşifoğlu ve Ercan, 2006). Aynı ölçme aracının kullanıldığı, İzmir'de yapılan bir araştırmada ise lise öğrencilerinin \%33.8'inin yaşamları boyunca en az bir kez sigara içtikleri, \%54.1'inin en az bir kez alkollü içki içtikleri ve \%31.6'sının en az bir kez sarhoş oldukları rapor edilmiştir (Çavdar, Çetinkaya Sümer, Eliaçık ve ark., 2016). Okul çağı çocuklarda sıklıkla kullanılan bir diğer madde türü de uçucu maddelerdir. Ögel, Tamar, Evren ve Çakmak'ın (2000) 15 farklı ilde yaşayan 20245 lise ikinci sınıf öğrencisine ulaşarak gerçekleştirdikleri araştırmada en az bir kere uçucu madde kullanmış olma oranının \%8.8 olduğunu ortaya çıkarılmıştır. Başka bir çalışmada uçucu maddelerin okul çağı çocuklarda kullanım oranının \%4.1 olduğu belirtilmiştir (Ögel ve ark., 2004). Madde bağımlılığı merkezine iki yıl boyunca başvuran 323 çocuk ve ergen üzerinde gerçekleştirilmiş 
Çetinkaya Yıldız, E. (2020). Okul psikolojik danışmanlarının madde bağımlılığı konusundaki görüş, bilgi ve yeterlikleri. Journal of Human Sciences, 17(2), 609-631. doi:10.14687/jhs.v17i2.5926

olan bir çalışmada katılımcıların madde kullanım oranları ve maddeyi ilk kullanma yaşları incelenmiştir. Katılımcıların en sık kullandığı maddelerin sırasıyla; sigara (\%94.4), esrar (\%75.2), inhalan (\%53.8), ekstazi (\%43.6), alkol (\%43.2), benzo (\%31.4), kokain (\%2.6), hap (diğer) (\%1.7), opioid (\%0.3) olduğu ortaya konmuştur. Sigara kullanımı hariç bırakıldığında merkeze başvuran kişilerin \%86.9’unun çoğul madde kullanıcısı oldukları tespit edilmiştir. Katılımcıların madde kullanmaya başlama yaşlarının ortalama $13.7 \pm 2.16$ olduğu belirtilmiştir (Yüncü, Aydın, Çoşkunol, Altıntoprak ve Bayram, 2006). Madde ilk kullanım yaşı ile ilgili olarak Sağlık Bakanlığı istatistikleri incelendiğinde madde bağımlılı̆̆ sebebiyle yatarak tedavi gören hastaların \%46'sının maddeyi ilk kullanım yaşlarının 19 yaş ve altı olduğu görülmektedir (TUBİM, 2018, s.42).

Madde kullanımı ergenlerde ve çocuklarda sosyal, ekonomik ve adli sonuçlara (Haskins, 2012) yol açarak gençlerin sağlıksız ve daha düşük yaşam kalitesiyle yaşamlarını sürdürmelerine neden olmaktadır (Godley ve White, 2005). İstatistiklerden ve araştırmalardan elde edilen bilgiler Türkiye'de genç nüfusun madde bağımlılığı konusunda risk altında olduğunu göstermektedir. Madde bağımlılı̆̆1 ile ilgili tüm bu veriler göz önünde bulundurulduğunda genç nüfusun en çok oranda bulunduğu ve zamanının çoğunu geçirdiği okullara ve dolayısıyla okul personeline madde bağımlılı̆̆1 konusunda bir takım rol ve sorumlulukların düşmesi kaçınılmazdır. Okul psikolojik danışmanları öğrencilerin karşılaştığı pek çok zorlukta onlara destek olmaktadır. Bu destek akademik, sosyal, psikolojik ya da zararlı alışkanlıklarla ilgili konularda olmaktadır (Sink, 2005). Son yıllarda okul psikolojik danışmanlarının rolleri; sorunlara çözüm bulandan sorunları öngören ve önleyene, bireye odaklanandan sisteme odaklanana ve okuldaki ofislerinde çalışmalar yapandan okulda ve toplumda bir lider olana doğru bir değişim göstermiştir (Lee, 2005). Okulda öğrencilerin karşı karşıya kaldığ1 sıkıntılı durumlara ilk müdahale eden ya da etmesi beklenen kissi de yine okul psikolojik danışmanlardır. Öğrencilerin karşılaştığ1 sorunun türüne göre okul psikolojik danışmanları ya kendileri soruna bir çözüm üretmeye çalışırlar ya da başka bir uzmana yönlendirme yaparak öğrencilerin ihtiyaçlarına göre alması gereken uygun yardımlara ulaşmalarını sağlarlar. Madde kullanımı gibi hassas bir konuda da öğrencilerin okul ortamında ilk başvuracakları kişilerin okul psikolojik danışmanları olması muhtemeldir. Yurtdışında konu ile ilgili olarak yürütülmüş araştırmalar öğrencilerin madde kullanımı ile ilgili sorunlarını okul psikolojik danışmanlarıyla konuşmayı tercih ettiklerini ortaya koymuştur (Mason, 1997; Palmer ve Ringwalt, 1988). Nitekim Özmen ve Kubanç'in (2013) Elazığ'da 11 okul müdürüne, müdür yardımcısına ve psikolojik danışmana ulaşarak yürüttüğü nitel bir çalışmada aynı okullarda çalışan okul müdürü, müdür yardımcısı ve psikolojik danışmanların okullarındaki madde kullanan öğrenci sayısına ilişkin soruya okul müdürlerinin 35, müdür yardımcılarının 4 ve psikolojik danışmanların 88 gibi birbirlerinden oldukça farklı rakamlar verdiği görülmüştür. Araştırmacılar rapor edilen oranlar arasındaki bu büyük farkı okul yöneticilerinin okulun adı çıkmasın diye mevcut vakaları saklama yoluna başvurmuş olabileceklerine bağlamışlardır.

Okullarda çalışan psikolojik danışmanların bağımlılıkla ilgili gerçekleştirdikleri çalışmalarda madde bağımlılığı konusundaki görüşleri, bilgileri ve yeterlikleri belirleyicidir. Erford, Newsome ve Rock (2007) madde kullanımı ile ilgili risk grubunda bulunan öğrencilerle çalışan okul psikolojik danışmanlarının madde bağımlılı̆̆ını değerlendirme ve hizmetlere erişim konularında yeterli bilgiye sahip olmaları gerektiğini vurgulamıştır. Madde bağımlllı̆̆ ile ilgili çalışmalar yapan okul psikolojik danışmanları için yeterlikler net bir şekilde tanımlanmamıştır. Ancak, Psikolojik Danışma ve İlişkili Alanların Akreditasyon Konseyi (CACREP, 2009) okul psikolojik danışmanı olmak isteyen öğrencilerin, çocuklarda ve ergenlerde madde kötüye kullanımı ile ilgili semptomları, bağımlılı̆̆ın yaşandığ1 evlerde yaşamanın işaretlerini ve semptomları bilmelerinin gerekli olduğunu vurgulamıştır. İlaveten, madde bağımlılığının etiolojisi, kuramları, önleme, müdahale ve tedavi stratejileri hakkında bilgi sahibi olmalarının gerekli olduğunu vurgulamıştır. Dolayısıyla, psikolojik danışmanların madde bağımlılığı ile ilgili görüşlerini, bilgi düzeylerini ve yeterliklerini anlamak oldukça önemlidir. Okul psikolojik danışmanlarının madde bağımlılı̆̆1 konusundaki mevcut uygulamalarını ve eğitim seviyelerini ortaya koyan çalışmaların çok az sayıda olduğu belirtilmektedir (Burrow-Sanchez ve Lopez, 2009). Araştırmacının bilgisi dâhilinde Türkiye'de okul psikolojik danışmanların madde bağımlılı̆̆1 ile ilgili görüşlerini, bilgilerini ve yeterliklerini ortaya çıkarmaya yönelik bir çalışmaya 
Çetinkaya Yıldız, E. (2020). Okul psikolojik danışmanlarının madde bağımlılığı konusundaki görüş, bilgi ve yeterlikleri. Journal of Human Sciences, 17(2), 609-631. doi:10.14687/jhs.v17i2.5926

rastlanmamıştır. Bu araştırmada okul psikolojik danışmanların; madde bağımlılı̆̆ ile ilgili görüşlerinin nasıl olduğu, madde bağımlllı̆̆ ile ilgili olarak bilgilerini nasıl değerlendirdikleri, madde bağımlllı̆̆ ile ilgili çalışmalar yapma konusundaki yeterliklerini nasıl gördükleri ve kıdemlerine göre madde bağımlılığ1 ile ilgili görüşlerinin, bilgi düzeylerinin ve yeterliklerinin farklılaşıp farklılaşmadığ1 araştırilmıştır.

\section{Araştırmanın Modeli}

\section{Yöntem}

$\mathrm{Bu}$ araştırmada psikolojik danışmanların madde bağımlılığ1 konusundaki görüşleri, bilgi düzeyleri ve madde bağımlıları ile çalışmalar yapma konusundaki yeterlikleri ve bu değişkenlerin kıdem ile ilişkisi ortaya çıkarılmaya çalışılmıştır. Dolayısıyla var olan bir durumu var olduğu şekliyle betimlemeyi amaçlayan tarama modelinin kullanılması tercih edilmiştir (Karasar, 2015).

\section{Çalışma Grubu}

Araştırmaya Türkiye'nin farklı şehirlerinde çalışmakta olan 340 okul psikolojik danışmanı internet üzerinden hazırlanan ankete cevap vermek suretiyle gönüllü olarak katılmıştır. Katılımciların yaşları 21-53, meslekteki kıdemleri ise 1-28 yıl arasında değişmektedir. Katılımcıların cinsiyet, yaş, medeni durum, kıdem ve bağımlılıkla ilgili hizmet içi eğitim alma durumlarına ilişkin bilgilerin frekans ve yüzdelik değerleri Tablo 1'de verilmisstir.

Tablo 1

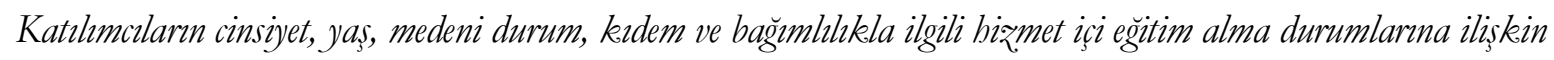
frekans ve yüzdelik de ğerleri

\begin{tabular}{|c|c|c|c|c|}
\hline & & $f$ & $\%$ & Yiğ. \% \\
\hline \multirow[t]{2}{*}{ Cinsiyet } & Kadin & 225 & 66.2 & 66.2 \\
\hline & Erkek & 115 & 33.8 & 100.0 \\
\hline \multirow[t]{3}{*}{ Yaş } & $20-30$ yaş & 243 & 71.5 & 71.2 \\
\hline & $31-40$ yaş & 75 & 22.1 & 93.5 \\
\hline & $41-53$ yaş & 22 & 6.5 & 100.0 \\
\hline \multirow[t]{2}{*}{ Medeni durum } & Bekâr & 165 & 48.5 & 48.5 \\
\hline & Evli & 175 & 51.5 & 100.0 \\
\hline \multirow[t]{3}{*}{ Kidem } & $0-5$ y1l & 225 & 66.2 & 66.2 \\
\hline & $6-10 \mathrm{y} 1 \mathrm{l}$ & 67 & 19.7 & 85.9 \\
\hline & 11 y1l ve üstü & 48 & 14.1 & 100.0 \\
\hline \multirow{2}{*}{ Bağımlılıkla ilgili hizmet içi eğitim alma } & Eğitim almış & 231 & 67.9 & 67.9 \\
\hline & Eğitim almamış & 109 & 32.1 & 100.0 \\
\hline
\end{tabular}

Katılımcı psikolojik danışmanların \%66.2'si kadın ve \%51.5’i evlidir. Katılımcıların \% $\% 1.5$ 'i 20-30 yaş aralığındadır. Buna paralel olarak, katılımcıların \%66.2'sinin meslekteki kıdemi 0-5 yıl aralığındadır. Son olarak katılımcıların \%67.9’u bağımlılık konusunda hizmet içi eğitim aldıklarını belirtmişlerdir.

\section{Veri Toplama Araçları}

Araştırmanın verisini toplamak için alanyazında kullanılmış bazı veri toplama araçları incelenmiş, bu anketlerden (Altıntaş, Temel, Benli ve ark., 2004; Burrow-Sanchez ve Lopez, 2009) faydalanılarak ve yeni maddeler eklenerek beş bölümden oluşan bir anket geliştirilmiştir. Hazırlanan 54 maddelik anket alanda çalışan uzmanların (rehberlik ve psikolojik danışma anabilim dalından üç öğretim üyesi, bir uzman psikolojik danışman ve bir okul psikolojik danışmanı) görüşüne sunulmuştur. Uzman görüşü alındıktan sonra 9 madde çıkarılmış ve anket 5 psikolojik danışmana uygulanarak anlaşıllırlığı test edilmiştir. İfadeler ön uygulamadan elde edilen veriler işı̆̆ında düzenlenmiş ve ankete 45 maddelik nihai şekli verilmiştir. Ankette bulunan beş bölüm ve başlıkları şu şekildedir: (a) Madde bağımlılı̆̆1 hakkında görüşler (9 madde), (b) Madde bağımlıllı̆ı hakkında bilgiler- maddeyi görünce tanıma (7 madde), (c) Madde bağımlılı̆̆ı hakkında bilgiler- bağımlılık yapan 
Çetinkaya Yıldız, E. (2020). Okul psikolojik danışmanlarının madde bağımlılığı konusundaki görüş, bilgi ve yeterlikleri. Journal of Human Sciences, 17(2), 609-631. doi:10.14687/jhs.v17i2.5926

maddeleri tanıma (11 madde), (ç) Madde bağımlılı̆̆ hakkında bilgiler- bağımllıkla ilgili bilgi düzeyi (8 madde), (d) Madde bağımlılığı ile ilgili çalışmalar yapma konusunda yeterlik (10 madde).

İşlem

Veriler çevrimiçi anket uygulaması ile toplanmıştır. Anket linki psikolojik danışmanların aktif olarak kullandığı sosyal medya grupları aracılı̆̆1 ile duyurulmuştur. Veriler betimleyici istatistik analizi yöntemleri ile analiz edilmiş yüzdelikler çıarılmıştır. Ayrıca ankette yer alan maddelere verilen cevapların okul psikolojik danışmanlarının meslekteki kıdemlerine göre farklılaşıp farklılaşmadığını anlamak için Ki kare analizi yapılmışıır.

\section{Bulgular}

$\mathrm{Bu}$ bölümde araştırmadan elde edilen bulgular sırasıyla psikolojik danışmanların madde bağımlılı̆̆ hakkındaki görüşleri, bilgi düzeyleri ve yeterlikleri sunulmuştur. Araştırmanın ilk sorusuna yönelik olarak psikolojik danışmanların madde bağımlılı̆̆ına ilişkin görüşlerini ortaya çıkarmak için ankette 9 madde bulunmaktadır. Bu bölümde yer alan maddelere okul psikolojik danışmanlarının verdiği cevapların yüzdelik dağılımları Tablo 2'de sunulmuştur.

\section{Tablo 2}

Okul psikolojïk danısmanlarmm madde bağımlılı̆ğ konusundaki görüsleri

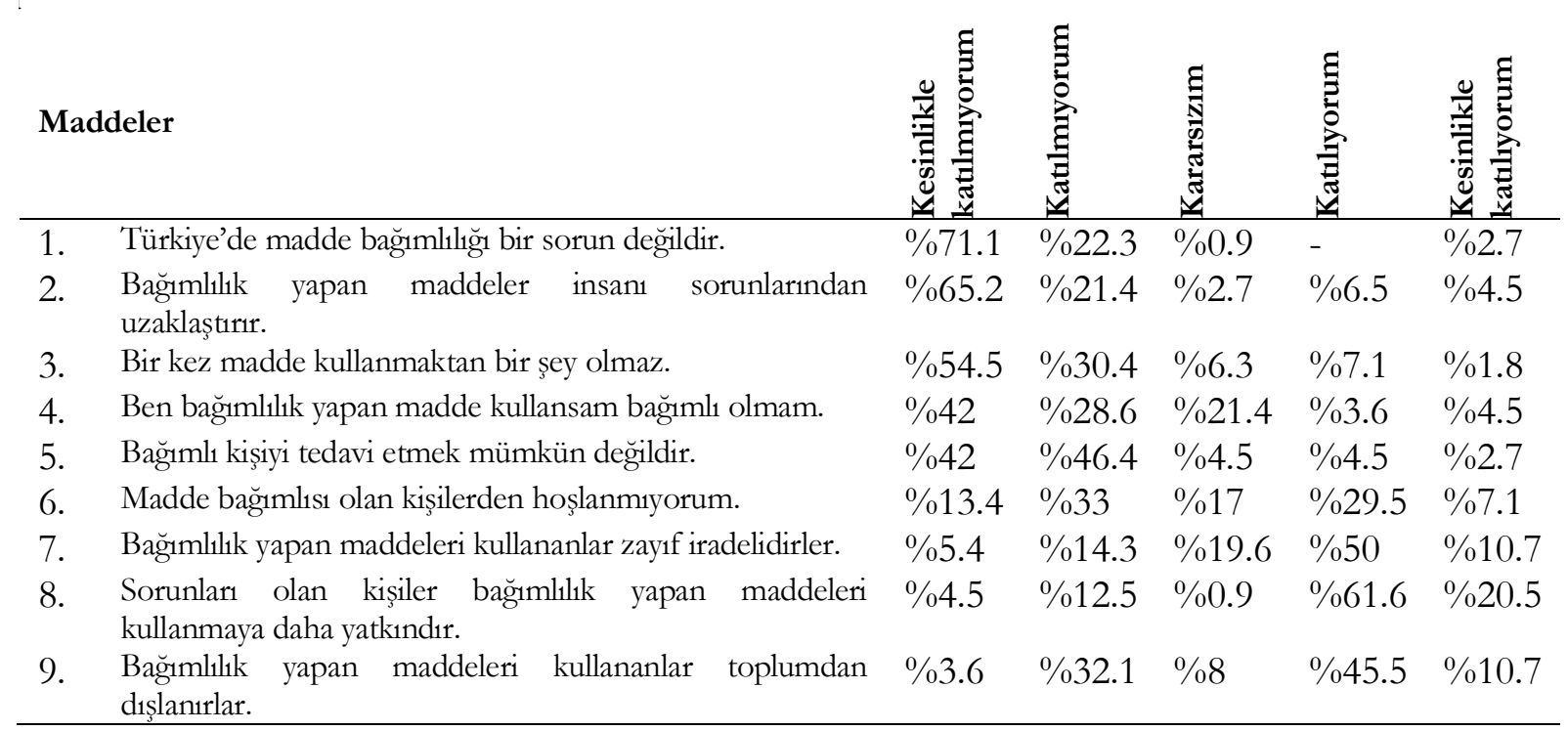

Tablo 2 incelendiğinde okul psikolojik danıșmanlarının "Türkiye'de madde bağımlılığı bir sorun değildir" (\%93.4), "bağımlı kişiyi tedavi etmek mümkün değildir" (\%88.4), "bağımllık yapan maddeler insanları sorunlarından uzaklaştırır" (\%86.6) ve "bir kez madde kullanmaktan bir şey olmaz" (\%84.9) ifadelerine yüksek oranda katılmadıkları belirlenmiștir. Ayrıca "sorunları olan kișiler bağımlılık yapan maddeleri kullanmaya daha yatkındır" ifadesine (\%82.1) yüksek oranda katıldıkları görülmektedir. Bununla birlikte, okul psikolojik danışmanlarının \%36.6'sı madde bağımlısı olan kişilerden hoşlanmadıklarını belirtmiştir. Tablo 3’te okul psikolojik danışmanlarının kıdemlerine göre madde bağımlılı̆̆ konusundaki görüşlerine ilişkin frekans dağılımı ve Ki kare istatistiğine yer verilmiştir. 
Çetinkaya Yıldız, E. (2020). Okul psikolojik danışmanlarının madde bağımlılığı konusundaki görüş, bilgi ve yeterlikleri. Journal of Human Sciences, 17(2), 609-631. doi:10.14687/jhs.v17i2.5926

Tablo 3

Okul psikolojïk danısmanlarmm kıdemlerine göre madde bağımlilŭg konusundaki görüslerine ilişkin frekans dağglım ve Ki kare istatistiği

\begin{tabular}{|c|c|c|c|c|c|c|c|c|}
\hline Maddeler & Kıdem & & 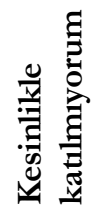 & 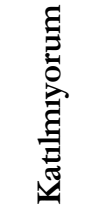 & 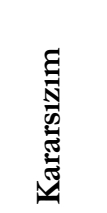 & E⿱艹⿹勹巳 & 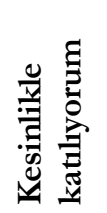 & $X^{2}$ \\
\hline \multirow{6}{*}{$\begin{array}{l}\text { Türkiye'de madde bağımlilı̆̆ bir } \\
\text { sorun değildir. }\end{array}$} & \multirow{2}{*}{5 yıla kadar } & $\mathrm{N}$ & 116 & 76 & 10 & 5 & 2 & \multirow{6}{*}{$\begin{aligned} X^{2} & =16.926 ; \\
p & <.05\end{aligned}$} \\
\hline & & $\%$ & $\% 55.5$ & $\% 36.4$ & $\% 4.8$ & $\% 2.4$ & $\% 1.0$ & \\
\hline & \multirow{2}{*}{$6-10$ y1l } & $\mathrm{N}$ & 30 & 25 & 9 & 1 & 2 & \\
\hline & & $\%$ & $\% 44.8$ & $\% 37.3$ & $\% 13.4$ & $\% 1.5$ & $\% 3.0$ & \\
\hline & \multirow{2}{*}{11 yll ve üzeri } & $\mathrm{N}$ & 24 & 26 & 10 & 1 & 3 & \\
\hline & & $\%$ & $\% 37.5$ & $\% 40.6$ & $\% 15.6$ & $\% 1.6$ & $\% 4.7$ & \\
\hline \multirow{6}{*}{$\begin{array}{l}\text { Bağımlılık yapan maddeler } \\
\text { insanı sorunlarından } \\
\text { uzaklaştırır. }\end{array}$} & \multirow{2}{*}{5 yıla kadar } & $\mathrm{N}$ & 110 & 60 & 16 & 17 & 6 & \multirow{6}{*}{$\begin{aligned} X^{2} & =18.866 \\
p & <.05\end{aligned}$} \\
\hline & & $\%$ & $\% 52.6$ & $\% 28.7$ & $\% 7.7$ & $\% 8.1$ & $\% 2.9$ & \\
\hline & \multirow{2}{*}{$6-10$ y1l } & $\mathrm{N}$ & 29 & 25 & 8 & 2 & 3 & \\
\hline & & $\%$ & $\% 43.3$ & $\% 37.3$ & $\% 11.9$ & $\% 3.0$ & $\% 4.5$ & \\
\hline & \multirow{2}{*}{11 yll ve üzeri } & $\mathrm{N}$ & 22 & 30 & 2 & 4 & 6 & \\
\hline & & $\%$ & $\% 34.4$ & $\% 46.9$ & $\% 3.1$ & $\% 6.3$ & $\% 9.4$ & \\
\hline \multirow{6}{*}{$\begin{array}{l}\text { Bir kez madde kullanmaktan bir } \\
\text { şey olmaz. }\end{array}$} & \multirow{2}{*}{5 yila kadar } & $\mathrm{N}$ & 106 & 68 & 19 & 6 & 10 & \multirow{6}{*}{$\begin{aligned} X^{2} & =15.908 \\
& p<.05\end{aligned}$} \\
\hline & & $\%$ & $\% 50.7$ & $\% 32.5$ & $\% 9.1$ & $\% 2.9$ & $\% 4.8$ & \\
\hline & \multirow{2}{*}{ 6-10 y1l } & $\mathrm{N}$ & 25 & 28 & 11 & 2 & 1 & \\
\hline & & $\%$ & $\% 37.3$ & $\% 41.8$ & $\% 16.4$ & $\% 3.0$ & $\% 1.5$ & \\
\hline & \multirow{2}{*}{11 yll ve üzeri } & $\mathrm{N}$ & 21 & 26 & 9 & 6 & 2 & \\
\hline & & $\%$ & $\% 32.8$ & $\% 40.6$ & $\% 14.1$ & $\% 9.4$ & $\% 3.1$ & \\
\hline \multirow{6}{*}{$\begin{array}{l}\text { Ben bağımlilık yapan madde } \\
\text { kullansam bağıml olmam. }\end{array}$} & \multirow{2}{*}{5 ylla kadar } & $\mathrm{N}$ & 90 & 63 & 33 & 19 & 4 & \multirow{6}{*}{$\begin{array}{c}X^{2}=11.854 \\
p>.05\end{array}$} \\
\hline & & $\%$ & $\% 43.1$ & $\% 30.1$ & $\% 15.8$ & $\% 9.1$ & $\% 1.9$ & \\
\hline & \multirow{2}{*}{ 6-10 y1l } & $\mathrm{N}$ & 25 & 17 & 12 & 7 & 6 & \\
\hline & & $\%$ & $\% 37.3$ & $\% 25.4$ & $\% 17.9$ & $\% 10.4$ & $\% 9.0$ & \\
\hline & 11 ry & $\mathrm{N}$ & 21 & 23 & 11 & 8 & 1 & \\
\hline & I yil ve uzeri & $\%$ & $\% 32.8$ & $\% 35.9$ & $\% 17.2$ & $\% 12.5$ & $\% 1.6$ & \\
\hline & & $\mathrm{N}$ & 90 & 70 & 31 & 11 & 7 & \\
\hline & 5 ylla kadar & $\%$ & $\% 43.1$ & $\% 33.5$ & $14.8 \%$ & $5.3 \%$ & $3.3 \%$ & \\
\hline Bağımlı kişiyi tedavi etmek & $610=10$ & $\mathrm{~N}$ & 15 & 31 & 15 & 3 & 3 & $X^{2}=19.408 ;$ \\
\hline mümkün değildir. & $0-10$ yil & $\%$ & $\% 22.4$ & $\% 46.3$ & $\% 22.4$ & $\% 4.5$ & $\% 4.5$ & $p<.05$ \\
\hline & & $\mathrm{N}$ & 19 & 19 & 21 & 4 & 1 & \\
\hline & 11 yul ve uzerı & $\%$ & $\% 29.7$ & $\% 29.7$ & $\% 32.8$ & $\% 6.3$ & $\% 1.6$ & \\
\hline & 5 vilo lador & $\mathrm{N}$ & 27 & 59 & 51 & 38 & 34 & \\
\hline & 5 уна каdar & $\%$ & $\% 12.9$ & $\% 28.2$ & $\% 24.4$ & $\% 18.2$ & $\% 16.3$ & \\
\hline Madde bağımlısı olan kişilerden & (10-10 & $\mathrm{N}$ & 6 & 12 & 19 & 15 & 15 & $X^{2}=5.863 ;$ \\
\hline hoşlanmiyorum. & 6-10 yll & $\%$ & $\% 9.0$ & $\% 17.9$ & $\% 28.4$ & $\% 22.4$ & $\% 22.4$ & $p>.05$ \\
\hline & & $\mathrm{N}$ & 7 & 19 & 16 & 9 & 13 & \\
\hline & T1 yul ve uzeri & $\%$ & $\% 10.9$ & $\% 29.7$ & $\% 25.0$ & $\% 14.1$ & $\% 20.3$ & \\
\hline & & $\mathrm{N}$ & 7 & 46 & 33 & 63 & 60 & \\
\hline & $5 \mathrm{~s}$ & $\%$ & $\% 3.3$ & $\% 22.0$ & $\% 15.8$ & $\% 30.1$ & $\% 28.7$ & \\
\hline Bağımlllık yapan maddeleri & & $\mathrm{N}$ & 3 & 12 & 11 & 22 & 19 & $X^{2}=4.134$ \\
\hline kullananlar zayıf iradelidirler. & $6-$ & $\%$ & $\% 4.5$ & $\% 17.9$ & $\% 16.4$ & $\% 32.8$ & $\% 28.4$ & $p>.05$ \\
\hline & 11 vil vë̈rì & $\mathrm{N}$ & 3 & 12 & 6 & 26 & 17 & \\
\hline & $11 \mathrm{y} 1 \mathrm{l}$ & $\%$ & $\% 4.7$ & $\% 18.8$ & $\% 9.4$ & $\% 40.6$ & $\% 26.6$ & \\
\hline & 5 rola lodar & $\mathrm{N}$ & 4 & 14 & 8 & 97 & 86 & \\
\hline & & $\%$ & $\% 1.9$ & $\% 6.7$ & $\% 3.8$ & $\% 46.4$ & $\% 41.1$ & \\
\hline $\begin{array}{l}\text { Sorunlarl olan k1şller bagimlilik } \\
\text { vapan maddeleri kullanmava }\end{array}$ & $610=0$ & $\mathrm{~N}$ & 1 & 5 & 3 & 25 & 33 & .131 \\
\hline & $0-10$ yil & $\%$ & $\% 1.5$ & $\% 7.5$ & $\% 4.5$ & $\% 37.3$ & $\% 49.3$ & \\
\hline & 11 vil & $\mathrm{N}$ & 3 & 8 & 6 & 18 & 29 & \\
\hline & 11 yil v & $\%$ & $\% 4.7$ & $\% 12.5$ & $\% 9.4$ & $\% 28.1$ & $\% 45.3$ & \\
\hline Bağımlilık yapan maddeleri & kadar & $\mathrm{N}$ & 7 & 44 & 35 & 77 & 46 & $X^{2}=13.501 ;$ \\
\hline kullananlar toplumdan dışlanırlar. & 5 yila kadar & $\%$ & $\% 3.3$ & $\% 21.1$ & $\% 16.7$ & $\% 36.8$ & $\% 22.0$ & $p>.05$ \\
\hline
\end{tabular}


Çetinkaya Yıldız, E. (2020). Okul psikolojik danışmanlarının madde bağımlılığı konusundaki görüş, bilgi ve yeterlikleri. Journal of Human Sciences, 17(2), 609-631. doi:10.14687/jhs.v17i2.5926

\begin{tabular}{ccccccc}
\multirow{2}{*}{ 6-10 y1l } & $\mathrm{N}$ & 4 & 11 & 16 & 18 & 18 \\
& $\%$ & $\% 6.0$ & $\% 16.4$ & $\% 23.9$ & $\% 26.9$ & $\% 26.9$ \\
\multirow{2}{*}{11 y1l ve üzeri } & $\mathrm{N}$ & 3 & 16 & 5 & 17 & 23 \\
& $\%$ & $\% 4.7$ & $\% 25.0$ & $\% 7.8$ & $\% 26.6$ & $\% 35.9$
\end{tabular}

Tablo 3 incelendiğinde okul psikolojik danışmanlarının kıdemlerine göre madde bağımlılı̆̆ına ilişkin "ben bağımlılık yapan madde kullansam bağımlı olmam, madde bağımlısı olan kişilerden hoşlanmıyorum, bağımlılık yapan maddeleri kullananlar zayıf iradelidirler, sorunları olan kişiler bağımlılık yapan maddeleri kullanmaya daha yatkındır ve bağımllık yapan maddeleri kullananlar toplumdan dişlanırlar" maddelerinde gruplar arasında anlamlı bir farklılık olmadığı görülmektedir. Bununla birlikte, beş yıldan az kıdemi olan okul psikolojik danışmanlarının "Türkiye'de madde bağımlılığı bir sorun değildir", "bağımlılık yapan maddeler insanı sorunlarından uzaklaştırır", "bir kez madde kullanmaktan bir şey olmaz" ve "bağımlı kişiyi tedavi etmek mümkün değildir" maddelerine daha yüksek oranda katılmadığı söylenebilir.

Okul psikolojik danışmanların madde bağımlllı̆ı ile ilgili bilgi düzeylerini ortaya çıkarmak için katılımcılara bazı bağımlılık yapan maddeleri görseler tanıyıp tanımayacakları sorulmuştur. Bu soruya ilişkin verilen yanıtların yüzdelikleri Tablo 4’te sunulmuştur.

Tablo 4

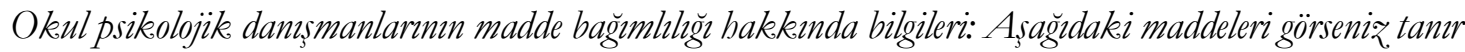
misinir?

\begin{tabular}{llll}
\hline & & Evet & Hayir \\
\hline 1. & Amfetamin & $\% 9.4$ & $\% 90.6$ \\
2. & LSD & $\% 10$ & $\% 90$ \\
3. & Esrar/Marihuana & $\% 13.2$ & $\% 86.8$ \\
4. & Kokain & $\% 23.2$ & $\% 76.8$ \\
5. & Eroin & $\% 32.1$ & $\% 67.9$ \\
6. & Bali & $\% 078.8$ & $\% 21.2$ \\
7. & Tiner & $\% 79.1$ & $\% 20.9$ \\
\hline
\end{tabular}

Tablo 4 incelendiğinde okul psikolojik danışmanların amfetamin, LSD, esrar/marihuana ve kokaini görseler tanımayacaklarına ilişkin yüksek oranlar ortaya çıkmıştır. Tablo 5 'te okul psikolojik danışmanlarının kıdemlerine göre bağımlılık yaratan maddeleri tanıma durumlarına ilişkin frekans dağ 11 mı ve Ki kare istatistiğine yer verilmiştir.

Tablo 5

Okul psikolojik danısmanlarmın kıdemlerine göre bağımlllk yaratan maddeleri tanmma durumlarna ilişkin frekans dağgllmı ve Ki kare istatistiği

\begin{tabular}{|c|c|c|c|c|c|}
\hline \multirow{2}{*}{ Maddeler } & \multirow{2}{*}{ Kidem } & & \multicolumn{2}{|c|}{ Bu maddeleri görseniz tanır misınız? } & \multirow{2}{*}{$X^{2}$} \\
\hline & & & Tan1rim & Tanımam & \\
\hline \multirow{6}{*}{ Amfetamin } & & $\mathrm{N}$ & 20 & 189 & \multirow{6}{*}{$\begin{array}{c}X^{2}=.282 \\
p>.05\end{array}$} \\
\hline & 5 ylla kadar & $\%$ & $\% 9.6$ & $\% 90.4$ & \\
\hline & & $\mathrm{N}$ & 7 & 60 & \\
\hline & $0-10$ yil & $\%$ & $\% 10.4$ & $\% 89.6$ & \\
\hline & \multirow{2}{*}{11 y1l ve üzeri } & $\mathrm{N}$ & 5 & 59 & \\
\hline & & $\%$ & $\% 7.8$ & \%92.2 & \\
\hline \multirow{6}{*}{ LSD } & \multirow{2}{*}{5 y1la kadar } & $\mathrm{N}$ & 25 & 184 & \multirow{6}{*}{$\begin{array}{c}X^{2}=3.192 ; \\
p>.05\end{array}$} \\
\hline & & $\%$ & $\% 12.0$ & $\% 88.0$ & \\
\hline & & $\mathrm{N}$ & 3 & 64 & \\
\hline & $0-10$ yil & $\%$ & $\% 4.5$ & $\% 95.5$ & \\
\hline & \multirow{2}{*}{11 y1l ve üzeri } & $\mathrm{N}$ & 6 & 58 & \\
\hline & & $\%$ & $\% 9.4$ & $\% 90.6$ & \\
\hline \multirow{3}{*}{ Esrar/Marihuana } & & $\mathrm{N}$ & 25 & 184 & \multirow{3}{*}{$\begin{array}{c}X^{2}=.780 \\
p>.05\end{array}$} \\
\hline & 5 y1la kadar & $\%$ & $\% 12.0$ & $\% 88.0$ & \\
\hline & $6-10 \mathrm{y} 1 \mathrm{l}$ & $\mathrm{N}$ & 10 & 57 & \\
\hline
\end{tabular}


Çetinkaya Yıldız, E. (2020). Okul psikolojik danışmanlarının madde bağımlılığı konusundaki görüş, bilgi ve yeterlikleri. Journal of Human Sciences, 17(2), 609-631. doi:10.14687/jhs.v17i2.5926

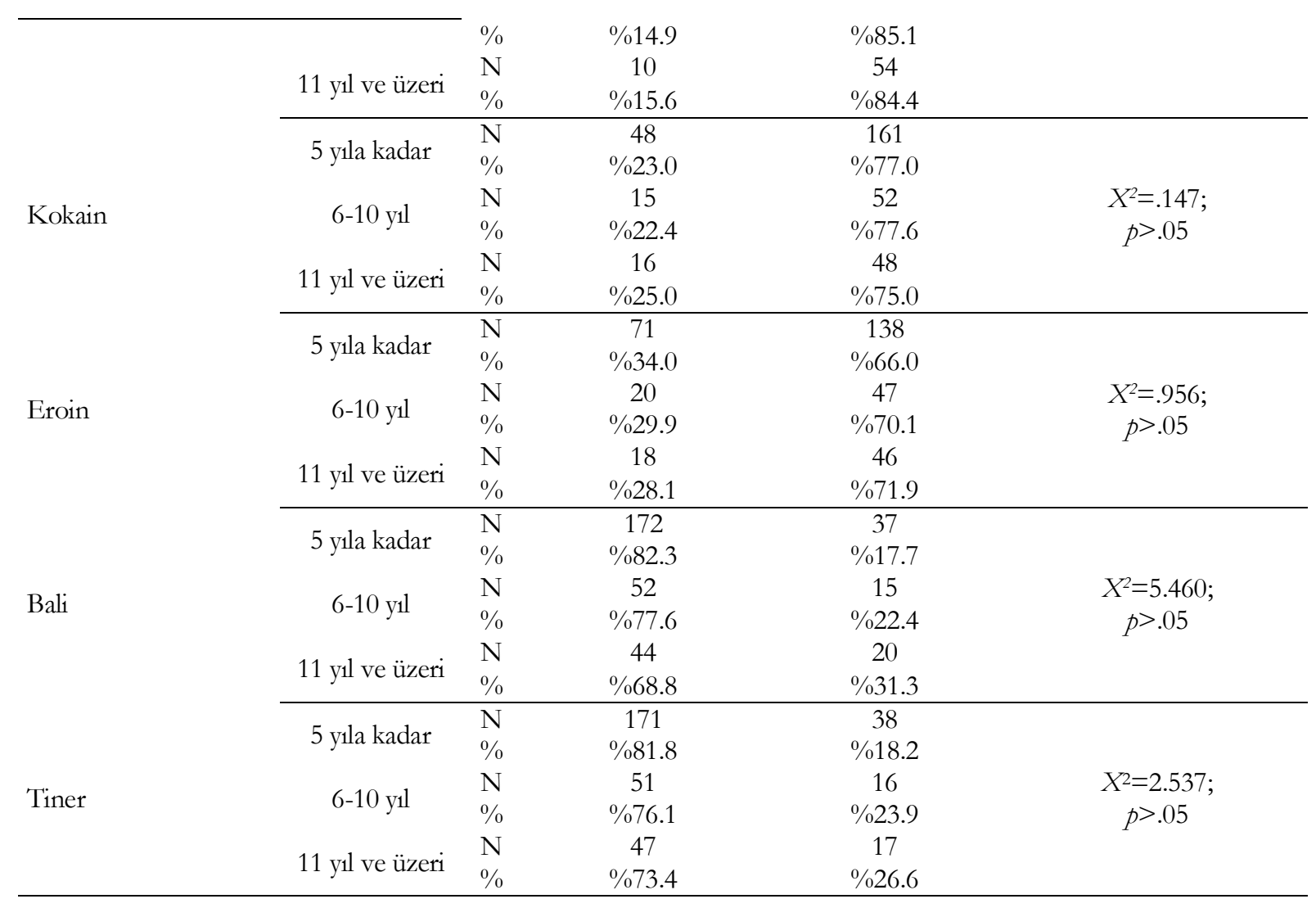

Tablo 5 incelendiğinde okul psikolojik danışmanlarının kıdemlerine göre amfetamin, LSD, esrar/marihuana, kokain, eroin, bali ve tiner maddelerini tanıma durumları bakımından gruplar arasında anlamlı bir farklılık olmadığı görülmektedir. Yine araştırmanın ikinci sorusuna yönelik olarak katılımcılara sigara, alkol, eroin, kokain, bali, esrar/marihuana, LSD, tiner, amfetamin, çakmak gazı ve nargilenin bağımlılık yapıp yapmadığı sorulmuştur. Katılımcıların bu maddelere verdiği cevapların yüzdelikleri Tablo 6'da sunulmuştur.

\section{Tablo 6}

Okul psikolojike damısmanlarmm madde bă̆ımlilğ̆ hakekında bilgileri: Aşağıdaki maddeler bağımlılık yapar mı?

\begin{tabular}{|c|c|c|c|}
\hline & & Evet & Hayı1 \\
\hline & Sigara & $\% 100$ & - \\
\hline 2. & Alkol & $\% 100$ & - \\
\hline 3. & Eroin & $\% 100$ & - \\
\hline 4. & Kokain & $\% 100$ & - \\
\hline 5. & Bali & $\% 99.4$ & $\% 0.6$ \\
\hline 6. & Esrar/Marihuana & $\% 98.2$ & $\% 1.8$ \\
\hline 7. & LSD & $\% 94.7$ & $\% 5.3$ \\
\hline 8. & Tiner & $\% 98.5$ & $\% 1.5$ \\
\hline 9. & Amfetamin & $\% 94.4$ & $\% 5.6$ \\
\hline 10. & Çakmak gazı & $\% 87.1$ & $\% 12.9$ \\
\hline 11. & Nargile & $\% 82.1$ & $\% 17.9$ \\
\hline
\end{tabular}

Tablo 6 incelendiğinde katılımcıların bağımlılık yapan maddeleri genel olarak ayırt edebildikleri görülmektedir. Bununla birlikte sigara ile aynı içeriğe sahip olmasına rağmen nargilenin bağımlılık yapmadığını belirtenlerin oranı (\%17.9) azımsanmayacak seviyededir. Benzer şekilde çakmak gazının bağımlılık yapmadığını belirten psikolojik danışmanların oranı da \%10'un üstündedir. Tablo 7'de okul psikolojik danışmanlarının kıdemlerine göre çeşitli maddelerin bağımlılık yapma durumu hakkındaki görüşlerine ilişkin frekans dağılımı ve Ki kare istatistiği verilmiştir. 
Çetinkaya Yıldız, E. (2020). Okul psikolojik danışmanlarının madde bağımllığı konusundaki görüşs, bilgi ve yeterlikleri. Journal of Human Sciences, 17(2), 609-631. doi:10.14687/ihs.v17i2.5926

\section{Tablo 7}

Okul psikolojik damısmanlarmm kıdemlerine göre çesitli maddelerin bağzmlllı. yapma durumu bakekndaki görïslerine ilişkin frekans dağgllm ve Ki kare istatistiği

\begin{tabular}{|c|c|c|c|c|c|}
\hline \multirow{2}{*}{ Maddeler } & \multirow{2}{*}{ Kıdem } & & \multicolumn{2}{|c|}{ Bu maddeler bağımlılık yapar mı? } & \multirow{2}{*}{$X^{2}$} \\
\hline & & & Yapar & Yapmaz & \\
\hline \multirow{8}{*}{ Sigara } & \multirow{2}{*}{5 y1la kadar } & $\mathrm{N}$ & 209 & 0 & \multirow{6}{*}{---} \\
\hline & & $\%$ & $\% 100.0$ & $\% 0$ & \\
\hline & & $\mathrm{N}$ & 67 & 0 & \\
\hline & $0-10$ yil & $\%$ & $\% 100.0$ & $\% 0$ & \\
\hline & \multirow{2}{*}{11 yll ve üzeri } & $\mathrm{N}$ & 64 & 0 & \\
\hline & & $\%$ & $\% 100.0$ & $\% 0$ & \\
\hline & \multirow{2}{*}{5 ylla kadar } & $\mathrm{N}$ & 209 & 0 & \multirow{6}{*}{---} \\
\hline & & $\%$ & $\% 100.0$ & $\% 0$ & \\
\hline \multirow{4}{*}{ Alkol } & \multirow{2}{*}{$6-10$ y1l } & $\mathrm{N}$ & 67 & 0 & \\
\hline & & $\%$ & $\% 100.0$ & $\% 0$ & \\
\hline & \multirow{2}{*}{11 yll ve üzeri } & $\mathrm{N}$ & 64 & 0 & \\
\hline & & $\%$ & $\% 100.0$ & $\% 0$ & \\
\hline \multirow{8}{*}{ Eroin } & \multirow{2}{*}{5 y1la kadar } & $\mathrm{N}$ & 209 & 0 & \multirow{6}{*}{---} \\
\hline & & $\%$ & $\% 100.0$ & $\% 0$ & \\
\hline & $6-10 \mathrm{~V} 1 \mathrm{l}$ & $\mathrm{N}$ & 67 & 0 & \\
\hline & $0-10 \mathrm{yll}$ & $\%$ & $\% 100.0$ & $\% 0$ & \\
\hline & \multirow{2}{*}{11 yll ve üzeri } & $\mathrm{N}$ & 64 & 0 & \\
\hline & & $\%$ & $\% 100.0$ & $\% 0$ & \\
\hline & & $\mathrm{N}$ & 209 & 0 & \\
\hline & 5 yila kadar & $\%$ & $\% 100.0$ & $\% 0$ & \\
\hline \multirow{6}{*}{ Kokain } & $6-10$ vil & $\mathrm{N}$ & 67 & 0 & \\
\hline & $0-10$ yil & $\%$ & $\% 100.0$ & $\% 0$ & --- \\
\hline & & $\mathrm{N}$ & 64 & 0 & \\
\hline & 11 yil ve uzerı & $\%$ & $\% 100.0$ & $\% 0$ & \\
\hline & & $\mathrm{N}$ & 207 & 2 & \\
\hline & 5 ylla kadar & $\%$ & $\% 99.0$ & $\% 1.0$ & \\
\hline & & $\mathrm{N}$ & 67 & 0 & $X^{2}=1.261$ \\
\hline Ball & $0-10$ yil & $\%$ & $\% 100.0$ & $\% 0.0$ & $p>.05$ \\
\hline & & $\mathrm{N}$ & 64 & 0 & \\
\hline & 11 yil ve uzerı & $\%$ & $\% 100.0$ & $\% 0.0$ & \\
\hline & & $\mathrm{N}$ & 205 & 4 & \\
\hline & 5 yila kadar & $\%$ & $\% 98.1$ & $\% 1.9$ & \\
\hline & & $\mathrm{N}$ & 67 & 0 & $X^{2}=1.914$ \\
\hline Esrar/Marihuana & 6-10 yil & $\%$ & $\% 100.0$ & $\% 0.0$ & $p>.05$ \\
\hline & 11 vyl ve üzeri & $\mathrm{N}$ & 62 & 2 & \\
\hline & 11 yil ve uzeri & $\%$ & $\% 96.9$ & $\% 3.1$ & \\
\hline & 5 vela kadar & $\mathrm{N}$ & 198 & 11 & \\
\hline & э уна kadar & $\%$ & $\% 94.7$ & $\% 5.3$ & \\
\hline LSD & & $\mathrm{N}$ & 64 & 3 & $X^{2}=.206$ \\
\hline & 6-10 yil & $\%$ & $\% 95.5$ & $\% 4.5$ & $p>.05$ \\
\hline & & $\mathrm{N}$ & 60 & 4 & \\
\hline & II yil ve uzerı & $\%$ & $\% 93.8$ & $\% 6.3$ & \\
\hline & & $\mathrm{N}$ & 207 & 2 & \\
\hline & 5 ylla kadar & $\%$ & $\% 99.0$ & $\% 1.0$ & \\
\hline & & $\mathrm{N}$ & 67 & 0 & $X^{2}=5.951 ;$ \\
\hline Tiner & 6-10 y1l & $\%$ & $\% 100.0$ & $\% 0.0$ & $p>.05$ \\
\hline & & $\mathrm{N}$ & 61 & 3 & \\
\hline & 11 yil ve uzer1 & $\%$ & $\% 95.3$ & $\% 4.7$ & \\
\hline & & $\mathrm{N}$ & 198 & 11 & \\
\hline & 5 yila kadar & $\%$ & $\% 94.7$ & $\% 5.3$ & \\
\hline Amfetamin & $6-10 \mathrm{vi1}$ & $\mathrm{N}$ & 63 & 4 & $X^{2}=.114$ \\
\hline & $0-10$ y1l & $\%$ & $\% 94.0$ & $\% 6.0$ & $p>.05$ \\
\hline & & $\mathrm{N}$ & 60 & 4 & \\
\hline & 11 yil ve üzeri & $\%$ & $\% 93.8$ & $\% 6.3$ & \\
\hline
\end{tabular}


Çetinkaya Yıldız, E. (2020). Okul psikolojik danışmanlarının madde bağımlılığı konusundaki görüş, bilgi ve yeterlikleri. Journal of Human Sciences, 17(2), 609-631. doi:10.14687/jhs.v17i2.5926

\begin{tabular}{|c|c|c|c|c|c|}
\hline \multirow{6}{*}{ Çakmak gazı } & & $\mathrm{N}$ & 179 & 30 & \multirow{6}{*}{$\begin{array}{c}X^{2}=1.152 ; \\
p>.05\end{array}$} \\
\hline & 5 ylla kadar & $\%$ & $\% 85.6$ & $\% 14.4$ & \\
\hline & & $\mathrm{N}$ & 59 & 8 & \\
\hline & $6-10 \mathrm{yll}$ & $\%$ & $\% 88.1$ & $\% 11.9$ & \\
\hline & \multirow{2}{*}{11 yll ve üzeri } & $\mathrm{N}$ & 58 & 6 & \\
\hline & & $\%$ & $\% 90.6$ & $\% 9.4$ & \\
\hline \multirow{6}{*}{ Nargile } & \multirow{2}{*}{5 y1la kadar } & $\mathrm{N}$ & 162 & 47 & \multirow{6}{*}{$\begin{array}{c}X^{2}=10.677 \\
p<.05\end{array}$} \\
\hline & & $\%$ & $\% 77.5$ & $\% 22.5$ & \\
\hline & 1 & $\mathrm{N}$ & 56 & 11 & \\
\hline & $0-10$ yil & $\%$ & $\% 83.6$ & $\% 16.4$ & \\
\hline & \multirow{2}{*}{11 yll ve üzeri } & $\mathrm{N}$ & 61 & 3 & \\
\hline & & $\%$ & $\% 95.3$ & $\% 4.7$ & \\
\hline
\end{tabular}

Tablo 7 incelendiğinde okul psikolojik danışmanlarının kıdemlerine göre sigara, alkol, eroin, kokain, bali, esrar/marihuana, LSD, tiner, amfetamin ve çakmak gazı maddelerinin bağımlılık yapma durumu hakkındaki görüşleri bakımından gruplar arasında anlamlı bir farklılık olmadığ1 görülmektedir. Bununla birlikte, 11 yıl ve üzeri kıdemi olan okul psikolojik danışmanlarının nargilenin bağımlılık yapma durumu konusundaki görüşlerinin diğer kıdemlerdeki okul psikolojik danışmanlara oranla daha yüksek olduğu söylenebilir. Katılımcıların madde bağımlılı̆g ile ilgili bilgi düzeylerini değerlendirmeleri için ankette sekiz madde yer almıştır. Katılımcıların bu maddelere verdiği yanıtların yüzdelikleri Tablo 8'de sunulmuştur.

\section{Tablo 8}

Okul psikolojike danısmanlarmm madde bağımlılğ̆ konusundaki bilgi düzeyleri

\begin{tabular}{|c|c|c|c|c|c|c|}
\hline & & 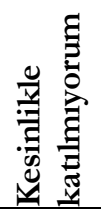 & 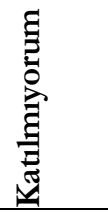 & 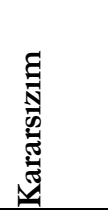 & 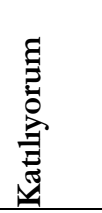 & 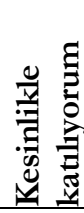 \\
\hline 1. & $\begin{array}{l}\text { Madde bağımlısı bir öğrencinin velisi ile nasil bir görüşme } \\
\text { yapmam gerektiğini biliyorum. }\end{array}$ & $\% 2.9$ & $\% 12.1$ & $\% 17.9$ & $\% 60.6$ & $\% 6.5$ \\
\hline 2. & $\begin{array}{l}\text { Madde bağımlısı bir öğrenciye nasıl yaklaşmam gerektiğini } \\
\text { biliyorum. }\end{array}$ & $\% 3.2$ & $\% 11.2$ & $\% 19.4$ & $\% 60.6$ & $\% 5.6$ \\
\hline 3. & Bağımllık ve beyin ilişkisini biliyorum. & $\% 3.5$ & $\% 13.8$ & $\% 21.5$ & $\% 52.9$ & $\% 8.2$ \\
\hline 4. & Bağımlılığın psikolojisini biliyorum. & $\% 3.2$ & $\% 16.2$ & $\% 20.9$ & $\% 53.2$ & $\% 6.5$ \\
\hline 5. & $\begin{array}{l}\text { Madde bağımlısı bir öğrenci ile karşılaştuğımda izlenmesi } \\
\text { gereken adımları biliyorum. }\end{array}$ & $\% 3.5$ & $\% 13.2$ & $\% 23.5$ & $\% 52.6$ & $\% 7.1$ \\
\hline 6. & Bağımllık tedavisinin nasıl olduğunu biliyorum. & $\% 5.3$ & $\% 19.7$ & $\% 38.5$ & $\% 32.9$ & $\% 3.5$ \\
\hline 7. & Madde bağımlilığı konusundaki bilgilerim yeterlidir. & $\% 10$ & $\% 41.8$ & $\% 19.4$ & $\% 25.9$ & $\% 2.9$ \\
\hline 8. & Uyuşturucu maddelerin hemen hepsini tanıyabilirim. & $\% 26.2$ & $\% 36.2$ & $\% 24.1$ & $\% 12.4$ & $\% 1.2$ \\
\hline
\end{tabular}

Tablo 8 incelendiğinde psikolojik danışmanların "Madde bağımlısı bir öğrencinin velisi ile nasıl bir görüşme yapmam gerektiğini biliyorum" maddesine $\% 67.1$ oranında, "madde bağımlısı bir öğrenciye nasıl yaklaşmam gerektiğini biliyorum" maddesine \%66.2 oranında ve "bağımlılık beyin ilişkisini biliyorum" maddesine \%61.1 oranında katıldıkları ortaya çıkmıştır. Buna karşın "bağımlılık tedavisinin nasıl olduğunu biliyorum" maddesine katıllyorum diyenlerin oran1 \%36.4, "madde bağımlılığ1 konusunda bilgilerim yeterlidir" maddesine katıliyorum diyenlerin oran1 \%28.8 ve "uyuşturucu maddelerin hemen hepsini tanıyabilirim" diyenlerin oranı ise \%13.6 olmuştur. Tablo 9'da okul psikolojik danışmanlarının kıdemlerine göre madde bağımlılığı konusundaki bilgi düzeylerine ilişskin frekans dağllımı ve Ki kare istatistiği verilmiştir. 
Çetinkaya Yıldız, E. (2020). Okul psikolojik danışmanlarının madde bağımlılığı konusundaki görüş, bilgi ve yeterlikleri. Journal of Human Sciences, 17(2), 609-631. doi:10.14687/jhs.v17i2.5926

\section{Tablo 9}

Okul psikolojik damısmanlarmm kıdemlerine göre madde bağmmlihğı konusundaki bilgi dürgylerine iliskin frekans dağglım ve Ki kare istatistiği

Madde bağımlısı bir öğrenciye nasıl

Madde bağımlısı bir öğrencinin velisi ile nasıl bir görüşme yapmam gerektiğini biliyorum. yaklaşmam gerektiğini biliyorum.

Bağımlılık ve beyin ilişkisini biliyorum.

\begin{tabular}{|c|c|c|c|c|c|c|c|}
\hline Kıdem & & 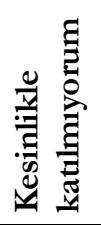 & 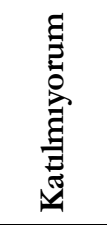 & 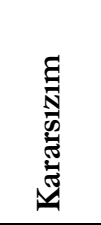 & 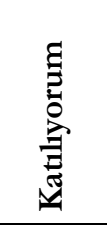 & 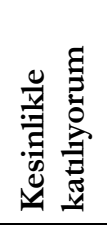 & $X^{2}$ \\
\hline \multirow{2}{*}{5 ylla kadar } & $\mathrm{N}$ & 3 & 25 & 26 & 108 & 47 & \multirow{6}{*}{$\begin{array}{c}X^{2}=25.483 ; \\
p<.05\end{array}$} \\
\hline & $\%$ & $\% 1.4$ & $\% 12.0$ & $\% 12.4$ & $\% 51.7$ & $\% 22.5$ & \\
\hline \multirow{2}{*}{ 6-10 yil } & $\mathrm{N}$ & 2 & 2 & 9 & 24 & 30 & \\
\hline & $\%$ & $\% 3.0$ & $\% 3.0$ & $\% 13.4$ & $\% 35.8$ & $\% 44.8$ & \\
\hline \multirow{2}{*}{$\begin{array}{c}11 \text { yll ve } \\
\text { üzeri }\end{array}$} & $\mathrm{N}$ & 3 & 7 & 14 & 19 & 21 & \\
\hline & $\%$ & $\% 4.7$ & $\% 10.9$ & $\% 21.9$ & $\% 29.7$ & $\% 32.8$ & \\
\hline \multirow{2}{*}{5 yila kadar } & $\mathrm{N}$ & 3 & 24 & 29 & 109 & 44 & \multirow{6}{*}{$\begin{array}{c}X^{2}=23.892 \\
p<.05\end{array}$} \\
\hline & $\%$ & \%1.4 & $\% 11.5$ & $\% 13.9$ & $\% 52.2$ & $\% 21.1$ & \\
\hline \multirow[b]{2}{*}{$6-10$ y1l } & $\mathrm{N}$ & 2 & 0 & 8 & 30 & 27 & \\
\hline & $\%$ & $\% 3.0$ & $\% 0.0$ & $\% 11.9$ & $\% 44.8$ & $\% 40.3$ & \\
\hline \multirow{2}{*}{$\begin{array}{c}11 \text { y1l ve } \\
\text { üzeri }\end{array}$} & $\mathrm{N}$ & 4 & 6 & 13 & 23 & 18 & \\
\hline & $\%$ & $\% 6.3$ & $\% 9.4$ & $\% 20.3$ & $\% 35.9$ & $\% 28.1$ & \\
\hline \multirow{2}{*}{5 yila kadar } & $\mathrm{N}$ & 6 & 16 & 33 & 104 & 50 & \multirow{6}{*}{$\begin{array}{c}X^{2}=14.190 ; \\
p>.05\end{array}$} \\
\hline & $\%$ & $\% 2.9$ & $\% 7.7$ & $\% 15.8$ & $\% 49.8$ & $\% 23.9$ & \\
\hline \multirow{2}{*}{ 6-10 y1l } & $\mathrm{N}$ & 1 & 7 & 8 & 35 & 16 & \\
\hline & $\%$ & $\% 1.5$ & $\% 10.4$ & $\% 11.9$ & $\% 52.2$ & $\% 23.9$ & \\
\hline \multirow{2}{*}{$\begin{array}{c}11 \text { yll ve } \\
\text { üzeri }\end{array}$} & $\mathrm{N}$ & 3 & 9 & 16 & 17 & 19 & \\
\hline & $\%$ & $\% 4.7$ & $\% 14.1$ & $\% 25.0$ & $\% 26.6$ & $\% 29.7$ & \\
\hline \multirow{2}{*}{5 yila kadar } & $\mathrm{N}$ & 4 & 24 & 40 & 97 & 44 & \multirow{6}{*}{$\begin{array}{c}X^{2}=8.095 \\
p>.05\end{array}$} \\
\hline & $\%$ & \%1.9 & $\% 11.5$ & \%19.1 & $\% 46.4$ & $\% 21.1$ & \\
\hline \multirow{2}{*}{ 6-10 y1l } & $\mathrm{N}$ & 3 & 6 & 12 & 25 & 21 & \\
\hline & $\%$ & $\% 4.5$ & $\% 9.0$ & $\% 17.9$ & $\% 37.3$ & $\% 31.3$ & \\
\hline \multirow{2}{*}{$\begin{array}{c}11 \text { y1l ve } \\
\text { üzeri }\end{array}$} & $\mathrm{N}$ & 2 & 9 & 12 & 21 & 20 & \\
\hline & $\%$ & $\% 3.1$ & $\% 14.1$ & $\% 18.8$ & $\% 32.8$ & $\% 31.3$ & \\
\hline \multirow{2}{*}{5 yıla kadar } & $\mathrm{N}$ & 4 & 22 & 45 & 97 & 41 & \multirow{6}{*}{$\begin{array}{c}X^{2}=16.385 \\
p<.05\end{array}$} \\
\hline & $\%$ & $\% 1.9$ & $\% 10.5$ & $\% 21.5$ & $\% 46.4$ & $\% 19.6$ & \\
\hline \multirow{2}{*}{$6-10 \mathrm{yll}$} & $\mathrm{N}$ & 2 & 3 & 8 & 28 & 26 & \\
\hline & $\%$ & $\% 3.0$ & $\% 4.5$ & $\% 11.9$ & $\% 41.8$ & $\% 38.8$ & \\
\hline \multirow{2}{*}{$\begin{array}{c}11 \text { y1l ve } \\
\text { üzeri }\end{array}$} & $\mathrm{N}$ & 4 & 7 & 12 & 24 & 17 & \\
\hline & $\%$ & $\% 6.3$ & $\% 10.9$ & $\% 18.8$ & $\% 37.5$ & $\% 26.6$ & \\
\hline \multirow{2}{*}{5 yila kadar } & $\mathrm{N}$ & 11 & 25 & 73 & 75 & 25 & \\
\hline & $\%$ & $\% 5.3$ & $\% 12.0$ & $\% 34.9$ & $\% 35.9$ & $\% 12.0$ & \\
\hline & $\mathrm{N}$ & 3 & 8 & 16 & 28 & 12 & $X^{2}=9.942$ \\
\hline & $\%$ & $\% 4.5$ & $\% 11.9$ & $\% 23.9$ & $\% 41.8$ & $\% 17.9$ & \\
\hline 11 yll ve & $\mathrm{N}$ & 2 & 11 & 21 & 16 & 14 & \\
\hline .. & $\%$ & $\% 3.1$ & $\% 17.2$ & $\% 32.8$ & $\% 25.0$ & $\% 21.9$ & \\
\hline & $\mathrm{N}$ & 22 & 73 & 61 & 33 & 20 & \\
\hline ida & $\%$ & $\% 10.5$ & $\% 34.9$ & $\% 29.2$ & $\% 15.8$ & $\% 9.6$ & \\
\hline & $\mathrm{N}$ & 2 & 14 & 16 & 20 & 15 & $X^{2}=23.850 ;$ \\
\hline & $\%$ & $\% 3.0$ & $\% 20.9$ & $\% 23.9$ & $\% 29.9$ & $\% 22.4$ & $p<.05$ \\
\hline $11 \mathrm{yll}$ ve & $\mathrm{N}$ & 4 & 15 & 17 & 13 & 15 & \\
\hline üzeri & $\%$ & $\% 6.3$ & $\% 23.4$ & $\% 26.6$ & $\% 20.3$ & $\% 23.4$ & \\
\hline & $\mathrm{N}$ & 51 & 64 & 46 & 40 & 8 & \\
\hline 5 ylla kadar & $\%$ & $\% 24.4$ & $\% 30.6$ & $\% 22.0$ & $\% 19.1$ & $\% 3.8$ & \\
\hline & $\mathrm{N}$ & 9 & 21 & 15 & 16 & 6 & $X^{2}=11.071$ \\
\hline $0-10$ y1l & $\%$ & $\% 13.4$ & $\% 31.3$ & $\% 22.4$ & $\% 23.9$ & $\% 9.0$ & $p>.05$ \\
\hline & $\mathrm{N}$ & 8 & 20 & 21 & 12 & 3 & \\
\hline y1l ve uzer1 & $\%$ & $\% 12.5$ & $\% 31.3$ & $\% 32.8$ & $\% 18.8$ & $\% 4.7$ & \\
\hline
\end{tabular}


Çetinkaya Yıldız, E. (2020). Okul psikolojik danışmanlarının madde bağımlılığı konusundaki görüş, bilgi ve yeterlikleri. Journal of Human Sciences, 17(2), 609-631. doi:10.14687/jhs.v17i2.5926

Tablo 9 incelendiğinde okul psikolojik danışmanlarının kıdemlerine göre madde bağımlılığı konusundaki "bağımllık ve beyin ilişkisini biliyorum, bağımlılığın psikolojisini biliyorum, bağımlılık tedavisinin nasıl olduğunu biliyorum, uyuşturucu maddelerin hemen hepsini taniyabilirim" maddelerine verdikleri cevapların gruplar arasında anlamlı bir şekilde farklılaşmadığı görülmektedir. Bununla birlikte, altı ile on yıl arasında kıdemi olan okul psikolojik danışmanlarının "madde bağımlısı bir öğrencinin velisi ile nasıl bir görüşme yapmam gerektiğini biliyorum", "madde bağımlısı bir öğrenciye nasıl yaklaşmam gerektiğini biliyorum", "madde bağımlısı bir öğrenci ile karşılaştığımda izlenmesi gereken adımları biliyorum" ve "madde bağımlılı̆̆1 konusundaki bilgilerim yeterlidir" maddelerine daha yüksek oranda katıldığı söylenebilir.

Okul psikolojik danışmanların madde bağımlılı̆̆ ile ilgili çalışmalar yapma konusundaki yeterliklerini nasıl gördüklerine ilişkin maddelere verdikleri yanıtların yüzdelik dağılımları Tablo 10'da sunulmuştur.

Tablo 10

Okul psikolojik damısmanlarmmn madde bağımlih̆ğ ile ilgili çalısmalar yapma konusundaki yeterlikleri

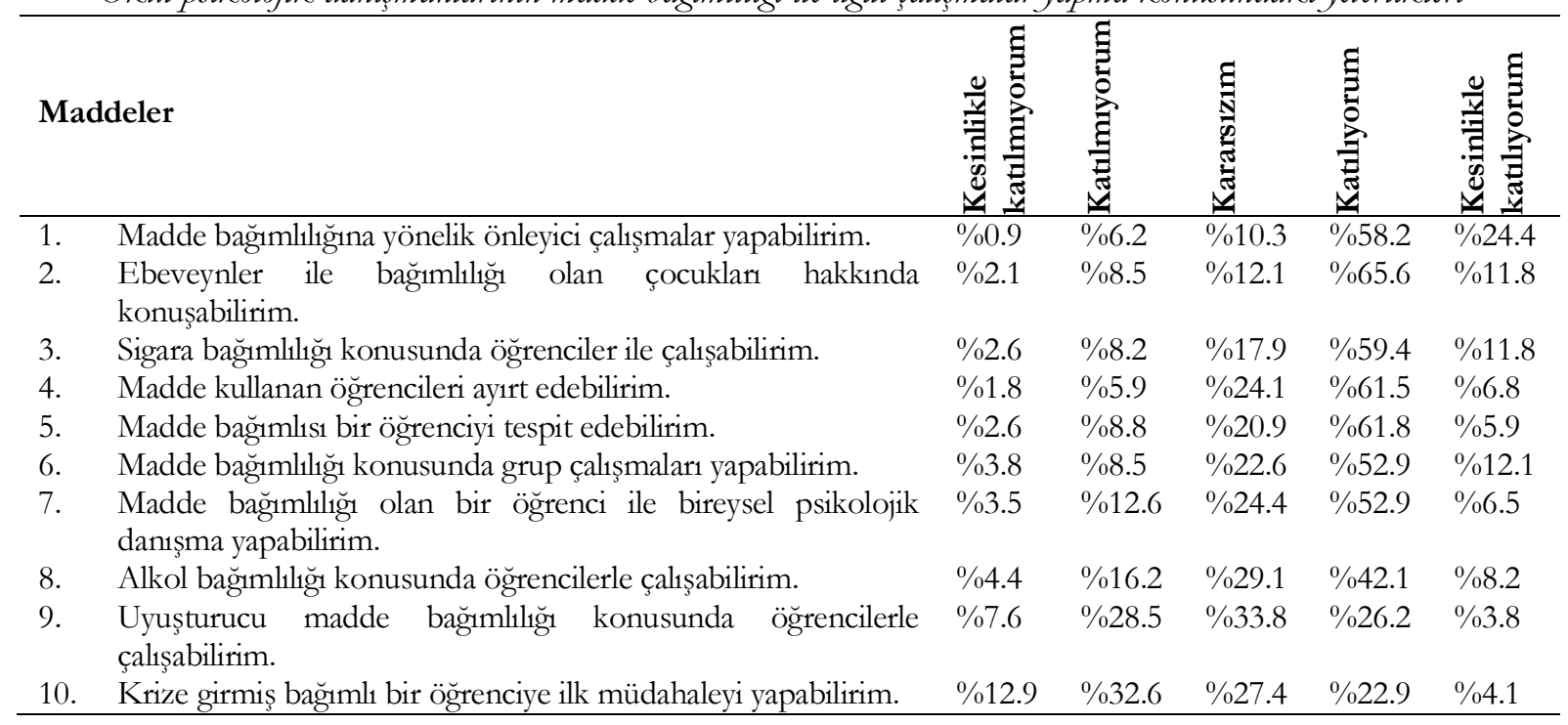

Tablo 10 incelendiğinde okul psikolojik danışmanlarının bağımlılıkla ilgili olarak kendilerini en yeterli gördükleri konular sırasıyla şunlardır; "madde bağımlılı̆ına yönelik önleyici çalışmalar yapabilirim" \%82.6; "ebeveynler ile bağımlılığı olan çocukları hakkında konuşabilirim” \% 077.4; "sigara bağımlılı̆̆1 konusunda öğrenciler ile çalışabilirim" \%71.2, "madde kullanan öğrencileri ayırt edebilirim" \%68.3 ve "madde bağımlısı bir öğrenciyi tespit edebilirim" \%67.7 dir. Bununla beraber, "uyuşturucu madde bağımlılı̆̆ı konusunda öğrencilerle çalışabilirim" maddesine katılıyorum diyen katılımcıların oranı \%30 ve "krize girmiş bağımlı bir öğrenciye ilk müdahaleyi yapabilirim" maddesine katılıyorum diyen katılımcıların oranı \%27 olmuştur. Tablo 11'de okul psikolojik danışmanlarının kıdemlerine göre madde bağımlllŭı ile ilgili çalışmalar yapmak konusundaki yeterliklerine ilişkin frekans dağıllımı ve Ki kare istatistiğine yer verilmiştir. 
Çetinkaya Yıldız, E. (2020). Okul psikolojik danıșmanlarının madde bağımlılığı konusundaki görüș, bilgi ve yeterlikleri. Journal of Human Sciences, 17(2), 609-631. doi:10.14687/jhs.v17i2.5926

\section{Tablo 11}

Okul psikolojik danısmanlarmın keıdemlerine göre madde bă̆ımhlĭ̆ ile ilgili çalısmalar yapma konusundaki yeterlikelerine ilisk kin frekans dağglım ve Ki kare istatistiği

\begin{tabular}{|c|c|c|c|c|c|c|c|c|}
\hline Maddeler & Kidem & & 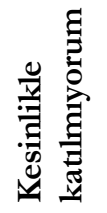 & 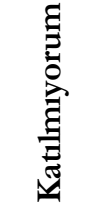 & 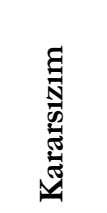 & 胥 & 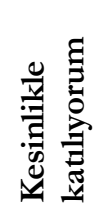 & $X^{2}$ \\
\hline \multirow{6}{*}{$\begin{array}{l}\text { Madde bağımliliğına yönelik } \\
\text { önleyici çalışmalar yapabilirim. }\end{array}$} & \multirow{2}{*}{5 y1la kadar } & $\mathrm{N}$ & 0 & 5 & 17 & 94 & 93 & \multirow{6}{*}{$\begin{array}{l}X^{2}=14.479 ; \\
p>.05\end{array}$} \\
\hline & & $\%$ & $\% 0.0$ & $\% 2.4$ & $\% 8.1$ & $\% 45.0$ & $\% 44.5$ & \\
\hline & \multirow{2}{*}{ 6-10 y1l } & $\mathrm{N}$ & 1 & 4 & 3 & 28 & 31 & \\
\hline & & $\%$ & $\% 1.5$ & $\% 6.0$ & $\% 4.5$ & $\% 41.8$ & $\% 46.3$ & \\
\hline & \multirow{2}{*}{$11 \mathrm{yll}$ ve üzeri } & $\mathrm{N}$ & 2 & 3 & 9 & 19 & 31 & \\
\hline & & $\%$ & $\% 3.1$ & $\% 4.7$ & $\% 14.1$ & $\% 29.7$ & $\% 48.4$ & \\
\hline \multirow{6}{*}{$\begin{array}{l}\text { Ebeveynler ile bağımlılığı olan } \\
\text { çocukları hakkında } \\
\text { konuşabilirim. }\end{array}$} & \multirow{2}{*}{5 ylla kadar } & $\mathrm{N}$ & 1 & 17 & 23 & 100 & 68 & \multirow{6}{*}{$\begin{aligned} X^{2} & =16.725 ; \\
& p<.05\end{aligned}$} \\
\hline & & $\%$ & $\% 0.5$ & $\% 8.1$ & $\% 11.0$ & $\% 47.8$ & $\% 32.5$ & \\
\hline & \multirow{2}{*}{ 6-10 y1l } & $\mathrm{N}$ & 2 & 3 & 6 & 25 & 31 & \\
\hline & & $\%$ & $\% 3.0$ & $\% 4.5$ & $\% 9.0$ & $\% 37.3$ & $\% 46.3$ & \\
\hline & \multirow{2}{*}{11 yll ve üzeri } & $\mathrm{N}$ & 4 & 2 & 9 & 23 & 26 & \\
\hline & & $\%$ & $\% 6.3$ & $\% 3.1$ & $\% 14.1$ & $\% 35.9$ & $\% 40.6$ & \\
\hline \multirow{6}{*}{$\begin{array}{l}\text { Sigara bağımliliğı konusunda } \\
\text { öğrenciler ile çalışabilirim. }\end{array}$} & \multirow{2}{*}{5 yıla kadar } & $\mathrm{N}$ & 3 & 17 & 26 & 104 & 59 & \multirow{6}{*}{$\begin{aligned} X^{2} & =17.641 ; \\
p & <.05\end{aligned}$} \\
\hline & & $\%$ & $\% 1.4$ & $\% 8.1$ & $\% 12.4$ & $\% 49.8$ & $\% 28.2$ & \\
\hline & \multirow{2}{*}{ 6-10 y1l } & $\mathrm{N}$ & 1 & 4 & 8 & 23 & 31 & \\
\hline & & $\%$ & $\% 1.5$ & $\% 6.0$ & $\% 11.9$ & $\% 34.3$ & $\% 46.3$ & \\
\hline & \multirow{2}{*}{11 yil ve üzeri } & $\mathrm{N}$ & 3 & 1 & 14 & 25 & 21 & \\
\hline & & $\%$ & $\% 4.7$ & $\% 1.6$ & $\% 21.9$ & $\% 39.1$ & $\% 32.8$ & \\
\hline \multirow{6}{*}{$\begin{array}{l}\text { Madde kullanan öğrencileri ayırt } \\
\text { edebilirim. }\end{array}$} & \multirow{2}{*}{5 yıla kadar } & $\mathrm{N}$ & 1 & 11 & 37 & 107 & 53 & \multirow{6}{*}{$\begin{array}{c}X^{2}=8.701 \\
\quad p>.05\end{array}$} \\
\hline & & $\%$ & $\% 0.5$ & $\% 5.3$ & $\% 17.7$ & $\% 51.2$ & $\% 25.4$ & \\
\hline & $6-10 \mathrm{vyl}$ & $\mathrm{N}$ & 1 & 3 & 13 & 25 & 25 & \\
\hline & $0-10$ yil & $\%$ & $\% 1.5$ & $\% 4.5$ & $\% 19.4$ & $\% 37.3$ & $\% 37.3$ & \\
\hline & \multirow{2}{*}{11 yll ve üzeri } & $\mathrm{N}$ & 2 & 3 & 12 & 26 & 21 & \\
\hline & & $\%$ & $\% 3.1$ & $\% 4.7$ & $\% 18.8$ & $\% 40.6$ & $\% 32.8$ & \\
\hline & & $\mathrm{N}$ & 3 & 15 & 34 & 112 & 45 & \\
\hline & 5 ylla kadar & $\%$ & $\% 1.4$ & $\% 7.2$ & $\% 16.3$ & $\% 53.6$ & $\% 21.5$ & \\
\hline Madde bağımlısı bir öğrenciyi & $610 \times 10$ & $\mathrm{~N}$ & 1 & 5 & 6 & 29 & 26 & $X^{2}=19.803 ;$ \\
\hline tespit edebilirim. & $0-10$ yil & $\%$ & $\% 1.5$ & $\% 7.5$ & $\% 9.0$ & $\% 43.3$ & $\% 38.8$ & $p<.05$ \\
\hline & 11 r1 ÿ̈еri & $\mathrm{N}$ & 3 & 5 & 14 & 19 & 23 & \\
\hline & I yul ve uzer1 & $\%$ & $\% 4.7$ & $\% 7.8$ & $\% 21.9$ & $\% 29.7$ & $\% 35.9$ & \\
\hline & 5 ralo lodor & $\mathrm{N}$ & 2 & 10 & 38 & 93 & 66 & \\
\hline & ว yila kadar & $\%$ & $\% 1.0$ & $\% 4.8$ & $\% 18.2$ & $\% 44.5$ & $\% 31.6$ & \\
\hline Madde bağımlilığ1 konusunda & $6-10 \mathrm{v} 1 \mathrm{c}$ & $\mathrm{N}$ & 2 & 5 & 10 & 32 & 18 & $X^{2}=23.080 ;$ \\
\hline grup çalışmaları yapabilirim. & $0-10$ yil & $\%$ & $\% 3.0$ & $\% 7.5$ & $\% 14.9$ & $\% 47.8$ & $\% 26.9$ & $p<.05$ \\
\hline & & $\mathrm{N}$ & 7 & 8 & 7 & 22 & 20 & \\
\hline & 11 yil ve uzenı & $\%$ & $\% 10.9$ & $\% 12.5$ & $\% 10.9$ & $\% 34.4$ & $\% 31.3$ & \\
\hline & & $\mathrm{N}$ & 3 & 21 & 41 & 100 & 44 & \\
\hline & 5 yila & $\%$ & $\% 1.4$ & $\% 10.0$ & $\% 19.6$ & $\% 47.8$ & $\% 21.1$ & \\
\hline Madde bağ1mliliğ1 olan bir & $6-10$ vil & $\mathrm{N}$ & 2 & 4 & 8 & 28 & 25 & $X^{2}=27.177 ;$ \\
\hline ogrenc1 1le bireysel psikoloj1k & 0- & $\%$ & $\% 3.0$ & $\% 6.0$ & $\% 11.9$ & $\% 41.8$ & $\% 37.3$ & $p<.05$ \\
\hline & 11 s1l yё̈еri & $\mathrm{N}$ & 5 & 6 & 21 & 15 & 17 & \\
\hline & 11 yil ve uzeri & $\%$ & $\% 7.8$ & $\% 9.4$ & $\% 32.8$ & $\% 23.4$ & $\% 26.6$ & \\
\hline & & $\mathrm{N}$ & 3 & 33 & 49 & 86 & 38 & \\
\hline & 5 yila kadar & $\%$ & $\% 1.4$ & $\% 15.8$ & $\% 23.4$ & $\% 41.1$ & $\% 18.2$ & \\
\hline Alkol bağımlilı̆̆1 konusunda & $6-10$ & $\mathrm{~N}$ & 1 & 4 & 14 & 28 & 20 & $X^{2}=23.762 ;$ \\
\hline öğrencilerle çalışabilirim. & $0-10$ yil & $\%$ & $\% 1.5$ & $\% 6.0$ & $\% 20.9$ & $\% 41.8$ & $\% 29.9$ & $p<.05$ \\
\hline & 11 s1l yё̈еri & $\mathrm{N}$ & 6 & 7 & 16 & 16 & 19 & \\
\hline & 11 yil ve uzern & $\%$ & $\% 9.4$ & $\% 10.9$ & $\% 25.0$ & $\% 25.0$ & $\% 29.7$ & \\
\hline & $5 \mathrm{y} 1 \mathrm{~B}$ & $\mathrm{~N}$ & 10 & 52 & 63 & 65 & 19 & $X^{2}=21,600$ \\
\hline & 5 уша каdar & $\%$ & $\% 4.8$ & $\% 24.9$ & $\% 30.1$ & $\% 31.1$ & $\% 9.1$ & $p<.05$ \\
\hline
\end{tabular}


Çetinkaya Yıldız, E. (2020). Okul psikolojik danışmanlarının madde bağımlılığı konusundaki görüş, bilgi ve yeterlikleri. Journal of Human Sciences, 17(2), 609-631. doi:10.14687/jhs.v17i2.5926

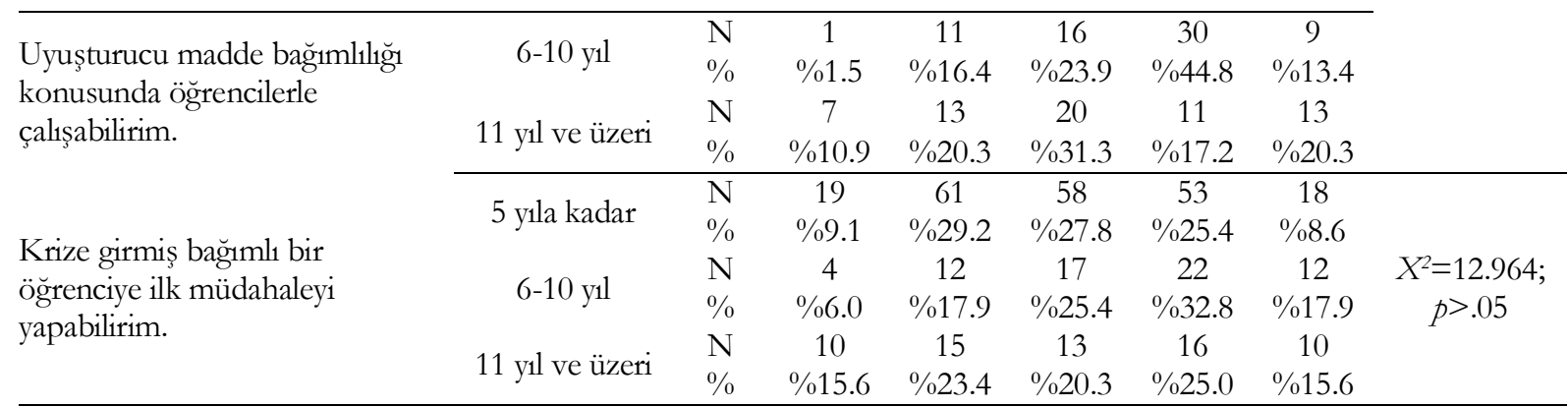

Tablo 11 incelendiğinde okul psikolojik danışmanlarının kıdemlerine göre madde bağımlılığı ile ilgili çalışmalar yapmak konusundaki "madde bağımlllığına yönelik önleyici çalışmalar yapabilirim, madde kullanan öğrencileri ayırt edebilirim, krize girmiş bağımlı bir öğrenciye ilk müdahaleyi yapabilirim." Maddelerine verdikleri yanıtlarda gruplar arasında anlamlı bir farklılık olmadığ1 görülmektedir. Bununla birlikte, altı ile on yıl arasında kıdemi olan okul psikolojik danışmanlarının "ebeveynler ile bağımlılı̆̆1 olan çocukları hakkında konuşabilirim", "sigara bağımlılı̆̆ konusunda öğrenciler ile çalışabilirim”, "madde bağımlısı bir öğrenciyi tespit edebilirim”, "madde bağımlılığı olan bir öğrenci ile bireysel psikolojik danışma yapabilirim”, "alkol bağımlılığı konusunda öğrencilerle çalışabilirim”, "uyuşturucu madde bağımlılığ konusunda öğrencilerle çalışabilirim” maddelerine daha yüksek oranda katıldığ1 söylenebilir. Ayrıca, beş yıldan az kıdemi olan okul psikolojik danışmanlarının "madde bağımlılığı konusunda grup çalışmaları yapabilirim" maddesine daha yüksek oranda katıldığ1 belirtilebilir.

\section{Sonuç, Tartışma ve Öneriler}

$\mathrm{Bu}$ araştırma psikolojik danışmanların madde bağımlılı̆̆ hakkındaki görüşlerini ortaya koyması ve madde bağımlllı̆ı ile ilgili bilgi düzeylerini ve yeterliklerini nasıl gördüklerini ortaya çıkarması bakımından önemli bilgiler sunmaktadır. Çalışmadan elde edilen bulgular, pek çok farklı kaynaktan madde bağımlılı̆̆ ile ilgili eğitimler almış olan psikolojik danışmanların gerçek ihtiyaçlarının neler olduğunu ortaya koyması bakımından önemlidir.

İlk olarak, psikolojik danışmanların madde bağımlılı̆̆ı konusundaki görüşleri incelenmiştir. Katılımcıların yüksek oranda görüş birliğine vardıkları konulardan biri Türkiye'de madde bağımlllı̆ı̆nın bir sorun olduğu maddesidir. Zaman zaman yazılı ve görsel medyada başka ülkelere kıyasla Türkiye'de madde bağımlılı̆̆ının ciddi bir sorun olmadığına ilişkin paylaşımlar yapılsa da okullarda gençlerle iç içe çalışan psikolojik danışmanların Türkiye'de madde bağımlılığının ciddi bir sorun olduğuna dair görüşleri önem taşımaktadır. Araştırmanın bu bulgusu daha önceki çalışmaların (Özmen ve Kubanç, 2013; Ulusoy, 2017) bulgularına paraleldir ve algılanan bu sorun karşısında psikolojik danışmanların madde bağımlilı̆̆ konusunda güçlendirilmesinin önemli olduğunu vurgulamıştır. Bununla birlikte, katılımcıların yaklaşık üçte biri madde bağımlısı olan kişilerden hoşlanmadıklarını belirtmişlerdir. Alan yazında sağlık görevlilerinin bağımlı kişilere yönelik olumsuz inançları olduğuna dair benzer bulgular mevcuttur (Maslach, Jackson ve Leither, 1997; Polonsky, Azbel, Wickersham, Taxman, Grishaev, Dvoryak ve Altice, 2015; Sleeper ve Boschain, 2013). Ayrica ruh sağlığı hizmeti sunan uzmanların bağımlılıkla ilgili görüşlerinin sundukları hizmetin kalitesini etkilediği belirtilen çalışmalar da bulunmaktadır (Lev-Ran ve ark, 2013; Tracy ve ark., 2009). Örneğin Vail-Smith, Knight ve White (1995) ebeveynleri madde bağımlısı olan ilkokul öğrencileri ile yürüttükleri araştırmada okul psikolojik danışmanlarının madde bağımlılığ1 ile ilgili kendi kissisel yaşantılarının sundukları hizmeti etkileyebileceğini vurgulamış ve öncelikle okul psikolojik danışmanlarının kendilerinin konu hakkında kişisel olarak çalışmalarını ve önyargılarını gidermelerini önermişlerdir. Araştırmanın bu bulgusu göz önünde bulundurulduğunda, psikolojik danışmanlara eğer bağımlılık konusunda olumsuz görüşleri varsa bu görüşlerini sorgulayıp değiştirebilecekleri birtakım eğitim süreçlerinden geçmeleri önerilebilir. 
Çetinkaya Yıldız, E. (2020). Okul psikolojik danıșmanlarının madde bağımlılığı konusundaki görüș, bilgi ve yeterlikleri. Journal of Human Sciences, 17(2), 609-631. doi:10.14687/jhs.v17i2.5926

Psikolojik danışmanların madde bağımlılı̆̆ı konusundaki bilgilerini değerlendirdikleri maddelere verdikleri yanıtlar incelendiğinde katılımcıların çoğunun yüksek düzeyde bağımllık yapan maddeleri görseler bile tanıyamayacaklarını ifade etmeleri dikkat çekici bir bulgudur. Bu bulgu okullarda çalışan ve bağımlılık yapan maddeleri tanıması beklenen psikolojik danışmanların konu hakkında bilgilendirmeye ihtiyaç duyduklarını göstermesi bakımından önemlidir. Benzer şekilde hangi maddelerin bağımlılık yapıp yapmadığ ile ilgili maddelere katılımcıların verdiği yanıtlar okul psikolojik danışmanlarının bağımlılık yapan maddeleri önemli ölçüde ayırt edebildiklerini ancak bağımlılık yapan bazı maddelerle (örn. nargile ve çakmak gazı) ilgili eksik bilgilerinin olduğunu ortaya koymuştur. Nargilenin bağımlılık yapıp yapmadığına ilişsin maddeye onbir yıl ve üstü kıdemi olan okul psikolojik danışmanlarının daha az kıdemi olan meslektaşlarına göre daha yüksek oranda evet yanıtını vermesi düşündürücüdür. Okul psikolojik danışmanlarının madde bağımlllğı konusundaki bilgi düzeylerini değerlendirdikleri maddelere verdikleri cevaplar değerlendirildiğinde katılımcıların madde bağımlılı̆̆ıla ilgili bilgilerini tam olarak yeterli bulmadıkları ortaya çıkmıştır. Araştırmanın bu bulgusu alan yazında okul psikolojik danışmanlarının (Vail-Smith, Knight ve White, 1995) ve sosyal hizmet uzmanlarının (Giannetti, Sieppert ve Holosko, 2002) bağımlılıkla ilgili bilgi eksiklikleri bulunduğunu rapor eden diğer araştırma bulguları ile benzerlik göstermektedir. Okul psikolojik danışmanlarının lisans eğitimleri sırasında ve mesleğe başladıktan sonra bağımlılıkla ilgili gerekli eğitimleri almamış olmaları ya da bağımlılığın fizyolojik ve tıbbi boyutunu sebebiyle konu hakkındaki bilgilerini yetersiz görmüş olabilecekleri düşünülmektedir. Ruh sağlığı uzmanlarının bağımlılıkla ilgili bilgi eksikliklerinin neden olabileceği sonuçlara bir örnek olarak Schenk ve Holosko'nun (1996) yaptı̆̆ araştırmanın bulguları verilebilir. Bu çalışmada araştırmacılar sosyal hizmet uzmanlarının alkolizmi bir hastalık olarak görmemelerini ve bağımlılı̆̆ın danışanın sosyal, duygusal ve medikal problemleri üzerindeki rolünü anlayamamalarının uygun olmayan değerlendirmeye ve tedaviye neden olduğunu belirtmişlerdir. Okul psikolojik danışmanlarının bağımlılığ olan gençlere, bağımlılı̆̆1 olan gençlerin ailelerine ve bağımlı ebeveyni olan çocuk ve ergenlere hizmet sunduğu göz önünde bulundurulduğunda; yeni ortaya çıkan maddeleri tanımaları, bağımlılık yapan maddeler hakkındaki son bilgilerini takip etmeleri, maddenin olası etkilerini bilmeleri ve bağımlı birey ve ailesi ile hangi aşamalarda ne tür çalışmalar yapabileceklerini bilmelerinin önemi ortaya çıkmaktadır. Nitekim bu bilgiler okullarda yürütecekleri birincil ve ikincil çalısmalar için büyük önem taşımaktadır.

Son olarak, okul psikolojik danışmanlarının madde bağımlılığı ile ilgili çalışmalar yapma konusundaki yeterliklerini değerlendirdikleri maddelere verdikleri cevaplar incelendiğinde psikolojik danışmanların koruyucu önleyici çalışmalar ve sigara bağımlılığı ile ilgili çalışmalar yapma konusundaki yeterliklerini daha yüksek, alkol ve uyuşturucu madde bağımlılığı ile ilgili çalısmalar yapma konusunda ise daha düşük gördükleri ortaya çıkmıştır. Araştırmanın bu bulgusu Bambgose, Hu ve Myers’in (2016) okul psikolojik danışmanlarının tarama/değerlendirme, grupla psikolojik danışma ve öğretim müfredatı ile ilgili konularda kendilerini yeterli görmediklerini rapor eden çalışmaları ile paraleldir. Aynı çalışmada okul psikolojik danışmanları bireysel psikolojik danışma, konsültasyon, tarama ve değerlendirme konularında eğitime ihtiyaç duyduklarını belirtmişlerdir. Psikolojik danışmanların okullarda daha çok koruyucu önleyici çalışmalar (örn. bağımlılık hakkında seminerler) yaptıkları düşünüldügünde bu konuda kendilerini daha yeterli görmeleri beklendik bir durumdur. Bu bulgu okul psikolojik danışmanlarının zaman sıkıntısı yaşamaları ya da yeterli şekilde ilgilenemeyeceklerini düşündüklerinden bağımlılıkla ilgili sorunları olan tüm öğrencileri diğer uzmanlara yönlendirmeleri ile de açıklanabilir. Okul psikolojik danışmanlarının zaman sıkıntısı nedeniyle bağımlı öğrencileri yönlendirmeyi tercih ettiklerine dair bulgulara (Burrow-Snchez ve Hawken, 2007; Burrow-Sanchez ve Lopez, 2009) alanyazında rastlamak mümkündür. Aslında bu durumun bir kısır döngüye neden oluyor olabileceği de gözden kaçırılmamalıdır. Şöyle ki; çeşitli eğitimlerden geçtiği halde zaman bulamadığı için ya da başka sebeplerle aşırı yönlendirme/sevk yapan psikolojik danışmanlar deneyim kazanamadıkları için madde bağımlılığı konusunda kendilerini geliştiremezler ve dolayısıyla kendilerini daima yetersiz görebilirler. Okul psikolojik danışmanının bir ruh sağlığı uzmanı olarak bağımlılık tedavisi sırasında ve sonrasında psikolojik destek sunabileceği bazı öğrencileri hali hazırda zaten çok fazla yoğunluğu olan sağlık kurumlarına yönlendirmesi gencin gerekli psikolojik desteği almasını daha 
Çetinkaya Yıldız, E. (2020). Okul psikolojik danışmanlarının madde bağımlılığı konusundaki görüş, bilgi ve yeterlikleri. Journal of Human Sciences, 17(2), 609-631. doi:10.14687/jhs.v17i2.5926

da zor hale getirebilmektedir. Bu nedenle okul psikolojik danışmanlarının madde bağımlılı̆̆ konusundaki yeterliklerinin geliştirilmesi ve sınırları dâhilinde bağımlılık konusunda sunabileceği psikolojik desteği öğrencilere sunması oldukça önemlidir.

Okul psikolojik danışmanlarının kıdemlerine göre madde bağımlılı̆̆ konusundaki görüşleri değerlendirildiğinde mesleğe yeni başlamış olan genç okul psikolojik danışmanlarının madde bağımlılı̆̆1 konusundaki farkındalıklarının kendilerinden daha kıdemli olan meslektaşlarına göre daha yüksek olduğunu söylenebilir. Bu bulgu son yıllarda okullarda ve medyada yürütülen çalışmaların ve büyük çaplı kampanyaların olumlu bir yansıması olarak yorumlanabilir. Araştırmada ayrıca, meslekte altı ile on yıl arasında kıdeme sahip olan okul psikolojik danışmanlarının madde bağımlılığı ile ilgili bilgi düzeylerini ve madde bağımlllı̆̆ ile ilgili çalışmalar yapma konusunda yeterliklerini değerlendirdikleri bazı maddelerde bilgi düzeylerini ve yeterliklerini meslekte daha az ve daha fazla kıdemi olan meslektaşlarına göre daha iyi gördükleri belirlenmiştir. Araştırmanın bu bulgusu mesleğe yeni başlayan psikolojik danışmanların kaygı, kusursuzluk çabası, belirsizlikle başa çıkabilme ve bir psikolojik danışman olarak rollerini belirleme gibi konularda yaşadıkları zorluklarla açılanabilir (Corey, 2008). Diğer taraftan, meslekte on yll ve daha fazla süredir çalışan deneyimli psikolojik danışmanların madde bağımlllı̆̆ konusundaki bilgilerini ve madde bağımlılı̆̆ı ile ilgili çalışmalar yapma konularındaki yeterliklerini düşük görmeleri şaşırtıcıdır. Bu bulgu araştırmaya katılan 11 yıl ve üstü kıdemi olan okul psikolojik danışmanlarının üniversiteden mezun olmalarının üzerinden çok yıl geçmiş olması ve alan bilgilerinin eskidiğini düşünmeleri ya da mesleki tükenmişlik (Bardhoshi, Schweinle ve Duncan, 2014) yaşamaları ile açıklanabilir. Ancak kıdem konusunda daha net bir şey söyleyebilmek için daha fazla çalışma yapılmasına ihtiyaç vardır.

Araştırmanın yeterlikler ile ilgili bulguları bağımlılık danışmanlığı ile ilgili konuların mevcut rehberlik ve psikolojik danışma lisans ve lisansüstü programlarında bulunmaması ile açıklanabilir. Bu konuya vurgu yapan Sales (1999) uzmanlık alanı ya da çalıştı̆̆ kurum ne olursa olsun tüm psikolojik danışmanların madde bağımlılı̆̆ ile ilgili doğrudan ya da dolaylı problemler yaşayan danışanlarla karşılaşacağını, ancak psikolojik danışman eğitiminin bu konudaki gerekli bilgi ve becerileri kapsamadığını belirtmiştir. Bu çalısmada da katılımcıların önemli bir kısmı madde bağımlılığı ile ilgili bilgilerini lisans eğitimleri sırasında değil TUBİM eğitimlerinde ya da kendi kişisel araştırmaları sonucunda kazandıklarını belirtmişlerdir. Eğitim programları ile ilgili bu yetersizliğin diğer pek çok ülkede de benzer süreçlerden geçilerek giderildiği söylenebilir. Örneğin Amerika Birleşik Devletleri’nde bağımlılık danışmanlığının uygulama standartları uzun bir süre önce oluşturulmuş olsa da eğitim standartları yakın bir zamana kadar oluşturulmamıştır. 2000'li yılların başından itibaren araştırmacılar bağımlılık danışmanlığı eğitim standartları ile ilgili ihtiyacı dile getirmiş ve uzmanlaşma alanlarına bakılmaksızın tüm psikolojik danışmanların bağımllık danışmanlığı standartlarını karşılayan bir eğitim almalarının gerekli olduğunu belirtmişlerdir (Hagedorn, 2007; Salyers, Ritchie, Cocrane ve Roseman, 2006; Whittinghill, Carroll ve Morgan, 2004; Whittinghill, 2006). CACREP ilk defa 2012 yılında bağımlılık danışmanlığı ile ilgili eğitim standartlarını yayınlamıştır. Hagedorn, Culbert ve Cashwell (2012) CACREP'in bağımlılık danışmanlığı akreditasyonu ile ilgili çalışmalarının hangi ihtiyaçları karşıladığını ve neleri içerdiğini ayrıntılı bir şekilde tartışmışlardır ve bu düzenleme ile psikolojik danışma mesleğinin daha da güçlendiğini belirtmişlerdir. Türkiye'de "Madde Bağımlilı̆̆1 Danışmanlığına İlişkin Ulusal Mesleki Standartlar" 2017 yılında Mesleki Yeterlik Kurumu tarafindan kabul edilmiş ve resmi gazatede yayınlanmıştır. Ancak yayınlanan bu statndartlar ile ilgili olarak bazı meslek derneklerinin itirazları devam etmektedir. Türkiye'de madde bağımlllı̆ı danışmanlığını bu konuda eğitim almış küçük bir grubun yaptığını belirtebiliriz çünkü bu konuda eğitim veren lisansüstü programlar hala az sayıda öğrenci kabul etmektedir. Bağımlılık danışmanlığı konusunda eğitim veren çevrimiçi ve yüzyüze sertifika programlarının ise ne derece yeterli olduğu tatışlır. Ruh sağllğı yasasının çıkmaması ve akreditasyon çalışmalarının tamamlanmamış olması gibi çeşitli sebeplerden dolayı bağımlılık danışmanlığı gibi çok önemli olan ve tüm ruh sağlığı alanını ilgilendiren bu konu standartları netleştirilmiş bir şekilde Türkiye'de ruh sağll̆ğ konusunda eğitim veren diğer programlara dâhil edilememiş ve dolayısıyla yaygınlaştırılamamıştır. 
Çetinkaya Yıldız, E. (2020). Okul psikolojik danışmanlarının madde bağımlılığı konusundaki görüş, bilgi ve yeterlikleri. Journal of Human Sciences, 17(2), 609-631. doi:10.14687/jhs.v17i2.5926

Türkiye'de madde bağımlılığı konusunda okullarda yürütülen çalışmalar son yıllarda YEŞİLAY ve MEB'in çalışmaları ile daha sistemli hale getirilmeye çalışılmaktadır. Türkiye Bağımlılıkla Mücadele Eğitim Programı kapsamında 712 formatör tarafindan 28.000 rehber öğretmene uygulayıcı eğitimi verilmiştir (TUBİM, 2018). Bunun dişında yine TUBİM raporunda belirtilen ve ikincil müdahale için geliştirilmiş olan Okulda Bağımlllı̆ga Müdahale (OBM) Programın'nın pilot çalışması yapılmış ve içerik geliştirme çalışmaları tamamlanıp uygulamaya hazır hale getirilmiştir. OBM programının rehber öğretmenlerin bağımllık riski taşıyan öğrenciye müdahale etme konusundaki becerilerini geliştirmek suretiyle önleyici çalışmaları daha verimli hale getirecek şekilde hazırlandığ1 belirtilmektedir. TUBİM (2018, s.32.) raporunda OBM Programı şu şekilde tanıtılmıstır: "OBM Program rehber ögretmenlerinin mesleki yeterlilik ve yetkinliklerini artturmakta; onlara müdahale becerileri, doğru iletişim ve yönlendirme özelliklerini kąandirmakta ve ikincil önleme çalısmalarm sistematik balde yapulandirmaktadır. OBM Program ile pek çok zararl davranus bağımlilĭga dönüsmeden okul temelli önlenecek ve ögrenciler eğitim sistemi dişına itilmeden kazanulacaktır. Çocuk ve ergen okulda bulunduğu sürece

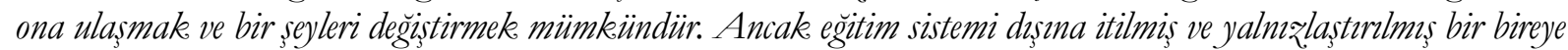
ulassmak ve onu zararl alşkanhğgndan uzaklastırmak çok daha zor olacaktır. OBM Program kapsaminda

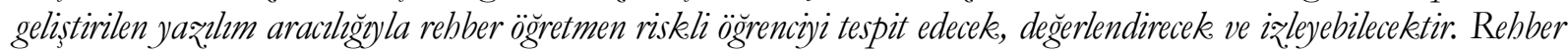
ögretmen yaz̨lm üzerindeki formlar aracliğgyla risk durumunu esas alarak ögrenciye önleyici müidahalede bulunacaktur. Bu müdahaleler bilgilendirmeden motivasyonel görüsmeye, iə̨lemeden aile ile temas kurmaya, psikososyal değerlendirmeden sağhle kurumlarna yönlendirmeye uz̨anan fark hyöntemler içermektedir." Yeşilay ve Millî Ë̆itim Bakanlığının çabalarıyla alana kazandırılan bu programın aktif bir şekilde okullarda kullanılmaya başlaması ve madde bağımlılı̆̆1 konusunda yapılacak çalışmaları sistematik hale getirmesi beklenmektedir. Ayrıca bu programın zaman içerisinde alandan gelen geri bildirimlerle daha da zenginleştirilmesi ve bölgesel ihtiyaçlara hitap eden ve sürekliliği olan bir çalışma olarak uygulanması oldukça önemlidir.

Bu çalışmanın psikolojik danışmanların madde bağımlılı̆̆ ile ilgili görüşlerini, bilgi düzeylerini ve yeterliklerini ortaya koyması bakımından alana katkı sağladığı düşünülmektedir. Ancak bulgular sınırlı sayıda katılımcıya internet üzerinden erişilen bir örneklem aracılı̆̆ıyla elde edildiğinden genellenebilirliği kısıtlıdır. Ayrıca, katılımcıların daha çok genç ve kıdemi düşük okul psikolojik danışmanlardan oluşması sonuçları etkilemiş olabilir. Dolayısıyla takip eden çalışmalarda daha büyük çaplı ve ulusal bir örnekleme ulaşılması önerilebilir. Farklı okul seviyeleri göz önünde bulundurularak çalışmanın tekrarlanması ve farklı seviyelerde çalışan psikolojik danışmanların ihtiyaçlarının ortaya çıkarılması da faydalı olabilir. Nitekim, alanyazında ilkokul ve ortaokulda, liseden biraz daha farklı olarak, önleyici çalışmalara daha fazla ağırlık verilmesinin gerekli olduğu belirtilmektedir (Brown, 2012).

Sonuç olarak, çalışmadan elde edilen bulgular doğrultusunda psikolojik danışmanların ihtiyaçlarına hitap eden ve onların madde bağımlılı̆̆1 konusunda rollerini daha net bir şekilde tanımlayan ve kendilerini yeterli görmedikleri alanlarda onları güçlendirecek düzenlemelerin yapılmasının gerekliliği ortaya çıkmıştır. Bu bağlamda, verilen hizmet içi eğitim programlarında okul psikolojik danışmanlarının kendi bireysel ihtiyaçlarına göre eğitim modülü seçebilecekleri, esnek eğitim programlarının hazırlanması, eğitim programlarının teorik ve uygulamalı bir içerik sunacak şekilde planlanması ve eğitimi tamamlayan okul psikolojik danışmanlarına bağımlı öğrencilerle ya da bağımlı ebeveyni olan çocuklarla çalışırken belirli bir süre süpervizyon desteğinin sağlanması önerilebilir. Ayrıca bağımlılık konusundaki çalışmaların okullarda daha sağlıklı bir şekilde yürütülebilmesi için ruh sağlı̆̆1 yasasının dünyadaki diğer örnekler göz önünde bulundurularak bir an önce yüyürlüğe konması, meslek standartlarının belirlenmesi ve rehber öğretmen kadrosuna alan dış1 atamamaların yapılmaması önerilebilir.

\section{Kaynaklar}

Alikaşifoğlu, M. ve Ercan O. (2006). Ergenlerde madde kullanımı. Türkiye Klinikleri Pediatrik Bilimler Dergisi, 2(5), 76-83. 
Çetinkaya Yıldız, E. (2020). Okul psikolojik danışmanlarının madde bağımlılığı konusundaki görüş, bilgi ve yeterlikleri. Journal of Human Sciences, 17(2), 609-631. doi:10.14687/jhs.v17i2.5926

Altıntaş H., Temel F., Benli E. ve ark. (2004). Tıp fakültesi birinci sınıf öğrencilerinin madde bağımlılığı ile ilgili bilgi, görüş ve tutumları. Bağımllhk Dergisi, 5, 107-14.

Arslan, H. N., Terzi, Ö., Dabak, Ş. ve Pekşen, Y. (2012). Substance, cigarette and alcohol use among high school students in the provincial center of Samsun, Turkey. Erciyes Medical Journal, 34, 79-84. doi:10.5152/etd.2012.19.

Bambgose, O. O., Hu, C., \& Myers, C. E. (2016). High school counselors' perceived competence in dealing with student alcohol and other drug issues. Vistas Online, 1-14. Retrieved from https://www.counseling.org/docs/default-source/vistas/article595df227f16116603abcacff 0000bee5e7.pdf?sfvrsn=c3e4472c_4

Bardhoshi, G., Schweinle, A., \& Duncan, K. (2014). Understanding the impact of school factors on school counselor burnout: A mixed-methods study. The Professional Counselor, 4(5), 426-443.

Birleşmiş Milletler Dünya Uyuşturucu Raporu (2016). United Nations Office on Drugs and Crime, World Drug Report 2016 (United Nations publication, Sales No. E.16.XI.7). Retrieved from http://www.unodc.org/doc/wdr2016/WORLD_DRUG_REPORT_2016_web.pdf

Birleşmiş Milletler Uyuşturucu ve Suç Ofisi-UNODC (2003). Madde kullanım üzerine ulusal değerlendirme çalssmasi: 6 büyü̈k sebirde elde edilen sonuclar. Ankara: Türkiye Proje Ofisi.

Brown, A. (2012). Preventing drug and alcohol use by school children. Community Practitioner, 85(2), 38-40.

Bulut, M., Savaş, H. A., Cansel, N., Selek, S., Kap, Ö., Yumru, M., ve Vırıt, O. (2006). Gaziantep Üniversitesi alkol ve madde kullanım bozuklukları birimine başvuran hastaların sosyodemografik özellikleri. Bağımlllke Dergisi, 7, 65-70

Burrow-Sanchez, J. J., \& Lopez, A. L. (2009). Identifying substance abuse issues in high school: A national survey of high school counselors. Journal of Counseling and Development, 87, 72-79. doi:10.1002/j.1556-6678.2009.tb00551.x

Burrow-Sanchez, J. J., \& Hawken, L. S. (2007). Helping students overcome substance abuse: Effective practices for prevention andintervention. New York: Guilford Press.

Çavdar, S., Sümer, E. Ç., Eliaçık, K., Arslan, A., Koyun, B., Korkmaz, N., ... Alikaşifoğlu, M. (2016). Health behaviors in high school students in Izmir, Turkey. Turkish Archives of Pediatrics/Türk Pediatri Arşivi, 51(1), 22-34. doi:10.5152/TurkPediatriArs.2016.3389

Corey, G. (2008). Psikolojik damısma kuram ve uygulamaları (T. Ergene, Çeviren). Ankara: Mentis Yayincilik.

Doğan, Y. B. (2001). Madde kullanımı ve bağımlılı̆̆1. Aile ve Toplum Dergisi, 1, 79-86.

Erdamar G, ve Kurupınar A (2014) Ortaöğretim öğrencilerinde görülen madde bağımlılığ1 alıskkanlığ1 ve yaygınlığı: Bartın ili örneği. Sosyal Bilimler Dergisi, 16 (1), $63-82$.

Erford, B. T., Newsome, D. W., \& Rock, E. (2007). Counseling youth at risk. In B. T. Erford (Ed.), Transforming the school counseling profession (2nd ed., pp. 279-303). Upper Saddle River, NJ: Merrill Prentice Hall.

ESPAD (2015). Substance use among students in 35 European countries. Stockholm.

Giannetti, V. J., Sieppert, J. D. \& Holosko, M. J. (2002). Attitudes and knowledge concerning alcohol abuse, Journal of Health \& Social Policy, 15(1), 45-58. doi:10.1300/J045v15n01_03

Godley, M. D., \& White, W. L. (2005). A brief history and some current dimensions of adolescent treatment in the United States. Recent Developments in Alcoholism, 17, 367-382.

Hagedorn, W. B. (2007). Accredited addiction counseling programs: The future is upon us. Journal of Addictions \& Offender Counseling, 28, 2-3.

Hagedorn, W. B., Culbert, J. R. \& Cashwell, C. S. (2012). Addiction counseling accreditation: CACREP's role in solidifying the counselling profession. The Professional Counselor, 2(2), 124133.

Haskins, N. H. (2012). The school counselor's role with students at-risk for substance abuse. Vistas: Ideas and research you can use.

Karakılınç, H. (1999). Antalya kent merkezindeki liselerin son sınıflarında okuyan öğrencilerin psikoaktif madde kullanım durumu. Sigara ve Sağlık Ulusal Kongresi, İstanbul, syf.30. 
Çetinkaya Yıldız, E. (2020). Okul psikolojik danıșmanlarının madde bağımlılığı konusundaki görüș, bilgi ve yeterlikleri. Journal of Human Sciences, 17(2), 609-631. doi:10.14687/jhs.v17i2.5926

Karasar, N. (2015). Bilimsel araştrma yöntemleri. Ankara: Nobel Yayın Dağıtım.

Lee, C. C. (2005). Urban school counseling: Context, characteristics, and competencies. Professional School Counseling, 8(3), 184-188.

Maslach, C., Jackson, S. E, \& Leiter, M. P. (1996). Maslach Burnout Inventory. (3rd ed.). Palo Alto, CA: Consulting Psychologists Press.

Mason, M. J. (1997). Patterns of service utilization for Mexican American majority students who use alcohol or other drugs. Journal of Health \& Social Policy, 9, 21-27. doi:10.1300/J045v09n02_02

Ögel, K, Tamar D, Evren ve Çakmak D. (2000). İstanbul'da lise gençleri arasında sigara, alkol ve madde kullanım yaygınlı̆̆, Klinik Psikizatri, 4, 242-345.

Ögel, K. Tamar, D., \& Çakmak D. (1998). A look to Turkey's situation regarding to substance abuse problem. Türk Psikiyatri Dergisi, 9(4), 301-307

Ögel, K., Çorapçığlu, A., Sır, A., Tamar, M., Tot, Ş., Doğan, O. ve ark. (2004). Dokuz ilde ilk ve ortaöğretim öğrencilerinde tütün, alkol ve madde kullanım yaygınlığı. Türk Psikìjatri Dergisi, 15, 112-118.

Özmen, F. ve Kubanç, Y. (2013). Liselerde madde bağımlılı̆̆1: Mevcut durum ve önerilere ilişkin okul müdürleri ve öğretmenlerin bakış açıları. Turkish Studies, 8(3), 357-382.

Palmer, J.H., \& Ringwalt, C.L. (1988). Prevalence of alcohol and drug use among North Carolina public school students. Journal of School Health, 58, 288-291. doi:10.1111/j.1746-1561. 1988.tb02318.x

Polonsky, M., Azbel. L., Wickersham, J. A, Taxman, F.S., Grishaev, E., Dvoryak, S., et al. (2015). Challenges to implementing opioid substitution therapy in Ukrainian prisons: Personnel attitudes toward addiction, treatment, and people with HIV/AIDS. Drug \& Alcohol Dependence, 148, 47-55. doi:10.1016/j.drugalcdep.2014.12.008

Sales, A. (1999). Substance abuse and counseling: A perspective. ERIC Digest. Greensboro, NC: ERIC Clearinghouse on Counseling and Student Services. (ERIC Document Reproduction Services No. ED435893)

Salyers, K., Ritchie, M., Cochrane, W., \& Roseman, C. (2006). Inclusion of substance abuse training in CACREP accredited programs. Journal of Addictions \& Offender Counseling, 27, 47-58. doi:10.1002/j.2161-1874.2006.tb00018.x

Schenk, C. \& Holosko, M. (1996). Identifying the elderly alcoholic: A niche for gerontological social work practice. In Holosko, M. J. \& Feit, M. D. (Eds.) Social Work Practice with the Elderly (2nd Edition). The Canadian Scholar's Press Inc: Toronto, ON.

Sink, C. (2005). Contemporary school counseling: Theory, research, and practice. Boston: Lahaska Press.

Sleeper, J. A., \& Boschain, S. S. (2013). Stigmatization by nurses as perceived by substance abuse patients: A phenomenological study. Journal of Nursing Education and Practice, 3(7), 92-98. doi:10.5430/jnep.v3n7p92

Lev-Ran, S., Adler, L., Nitzan, U., \& Fennig, S. (2013). Attitudes towards nicotine, alcohol and drug dependence among physicians in Israel. Journal of Substance Abuse Treatment, 44(1), 88-89. doi:10.1016/j.jsat.2012.04.001

Tracy, K., Brown, L.S., Kritz, S., et al. (2009). Substance abuse treatment clinician opinions and infectious disease service. Journal of Addiction Disorders, 28, 8-12. doi:10.1080/ 10550880802544625

TUBiM (2008). EMCDDA 2008 ulusal raporu. Türkiye: Yeni gelismeler, trendler, seçilmis konular. Ankara, Reitrox.

TUBİ (2011). EMCDDA 2011 ulusal raporu. "Türkiye” Yeni gelismeler, trendler, seçilmiş konular. Ankara, Reitrox.

Türkiye Uyuşturucu Raporu (2018). Emniyet Genel Müdürlüğü Narkotik Suçlarla Mücadele Daire Başkanlığı. Ankara.

Ulusoy, K. (2017). Tarih öğretmenlerinin madde bağımlılı̆̆ ve medya bağımlilı̆̆ ile ilgili düşünceleri. Kastamonu Eğitim Dergisi, 25(1), 385-400. 
Çetinkaya Yıldız, E. (2020). Okul psikolojik danışmanlarının madde bağımlılığı konusundaki görüş, bilgi ve yeterlikleri. Journal of Human Sciences, 17(2), 609-631. doi:10.14687/jhs.v17i2.5926

Ünlü, A. ve Evcin, U. (2010). İstanbul'da liseli gençler arasındaki madde kullanım yaygınlığ1 ve demografik faktörlerin etkileri. Literature Symposium, 1(2), 2-11.

Vail-Smith, K., Knight, S. M. \& White, D. M. (1995). Children of substance abusers in the elementary school: A survey of counselor perceptions. Elementary School Guidance \& Counseling, 29(3), 163176.

White, D., \& Pitts, M. (1998). Educating young people about drugs: A systematic review. Addiction, 93, 1475-1487. doi:10.1046/j.1360-0443.1998.931014754.x

Whittinghill, D. (2006). A preliminary investigation of the components of a curriculum for the preparation of master's-level addiction counselors. Journal of Drug Education, 36, 357-371. doi:10.2190/R7Q1-7521-7865-6222

Whittinghill, D., Carroll, J., \& Morgan, O. (2004). Curriculum standards for the education of professional substance abuse counselors. Journal of Teaching in the Addictions, 3, 63-76. doi:10.1300/J188v03n02_06

Yüncü, Z., Aydın, C., Çoşkunol, H., Altıntoprak, E., ve Bayram, A. T. (2006). Çocuk ve ergenlere yönelik bir bağımlılık merkezine iki yll süresince başvuran olguların sosyodemografik değerlendirilmesi. Bağımllık Dergisi, 7(1), 31-37.

\section{Introduction}

\section{Extended English Summary}

Within the school setting, school counselors are responsible for offering support to students in a variety of ways. This support can be academic, social, and psychological or it may be related to the risky behaviors such as substance addiction. School counselors are the first people who intervene or who are expected to intervene in the problems that students face. Whatever the problems it is, school counselors try to identify a solution to the problem or help students receive appropriate support through referral. Although school counselors are not expected to be expertly trained in substance addiction counseling, they are expected to possess a specific set of knowledge and skills concerning substance addiction. There are various tasks, mainly preventative tasks that a school counselor should implement about substance abuse and addiction. Thus, it is vital to understand school counselors' opinions, knowledge, and competencies regarding substance addiction. With this purpose, the study seeks answers to these four questions: (1) What are the opinions of school counselors about substance addiction? (2) How do school counselors perceive their knowledge on substance addiction? (3) How do school counselors perceive their competencies about substance addiction? (4) Do the school counselors' opinions, knowledge and competencies on substance addiction differ according to their proffesional experience?

\section{Method}

This study is a descriptive study. Three hundred and forty school counselors participated in the study by answering the online questionnaire, $66.2 \%$ of the participants were female, $51.8 \%$ were married, $71.5 \%$ of the participants' age ranged between 20 to 30 , and $66.2 \%$ of the participants had proffesional experience less than 5 years. Finally, $67.9 \%$ of the participants stated that they had received in-service education regarding substance addiction.

In order to collect data, a questionnaire was developed after examining several related data collection tools from the literature (Altıntaş, Temel, Benli et al., 2004; Burrow-Sanchez \& Lopez, 2009). The first form was a 54-item questionnaire that was sent to the proffesionals in the counseling field (three faculty members from the department of guidance and psychological counseling, one expert psychological counselor, and one school psychological counselor) for expert opinion. According to feedbacks, nine items were removed from the questionnaire. Later, a pilot study was conducted with five counselors to check the clarity of the items. A few minor problems with the items were handled and the 45-item questionnaire was finalized. The sections of the questionnaire were as follows: (a) opinions on substance addiction (9 items), (b) information on substance addiction: recognizing the substance ( 7 items), (c) information on substance addiction: knowing the addictive substances (11 items), (d) information on substance addiction (8 items), and (e) competence 
Çetinkaya Yıldız, E. (2020). Okul psikolojik danıșmanlarının madde bağımlılığı konusundaki görüș, bilgi ve yeterlikleri. Journal of Human Sciences, 17(2), 609-631. doi:10.14687/jhs.v17i2.5926

in working with substance addiction (10 items).

Data were collected through an online survey application. The link for the questionnaire was shared through social media groups, which school counselors actively use. In order to analyse data, descriptive statistics and percentages were calculated first. Later, Chi square analysis were used to find out whether the answers given to the questionnaire items differ according to the proffesional experience of the school counselors.

\section{Findings}

The school counselors' opinions on substance addiction were measured through their answers to nine items. The items that school counselors reached consensus on are as follows; "substance addiction is not a problem in Turkey" (93.4\% Disagree), "substances that cause addiction distract people from their problems" (86.6\% Disagree), "Using the addictive substance once is not a problem" (84.9.7\% Disagree), "people with problems are more likely to use addictive substances" (82.1\% Agree).

In order to find out school counselors' knowledge on substance addiction the participants were asked whether they would recognize the substances. Among the participants, $90.6 \%$ stated that they would not recognize amphetamine; $90 \%$ stated that they would not recognize LSD; $86.8 \%$ stated that they would not recognize marijuana; $76.8 \%$ stated that they would not recognize cocaine; $67.9 \%$ state dthat they would not recognize heroin; $57.4 \%$ stated that they would not recognize amphetamine; $93.8 \%$ stated that they would not recognize LSD, and $83.9 \%$ stated that they would not recognize heroine. Second, school counselors were asked about 11 substances, whether they are addictive or not (cigarette, alcohol, heroin, cocaine, glue, marijuana, LSD, solvent, amphetamine, lighter fluid, hookah). When the findings were examined, it was found out that the participants can distinguish the addictive substances in general. However, although it has the same content as cigarettes, the number of participants stating that hookah is not addictive was higher. Lastly, eight questions were asked to the participants in order to reveal their level of knowledge on substance addiction. Some of the questions in the questionnaire and the responses with the highest percentages were: "I know how to approach to a drug addict student" (66.2\% Agree), "I know how to interview with a parent of a drug addict student" (67.1\% Agree), and "my knowledge of substance addiction is sufficient" (58.1\% Agree).

To reveal the school counselors' competence on substance addiction, ten questions were asked. Some of the questions and their percentages are as follows: "I can do preventive activities for substance addiction" (82.6\%), "I can work with students about smoking addiction" (71.2\%), "I can distinguish students who use substance" (68.3\%), and "I can identify a substance addict student" $(67.7 \%)$. Moreover, $30 \%$ of the participants stated that they can work with a substance addict student and $27 \%$ of the participants stated that they can intervene to a substance addict student who is in crisis.

In order to investigate whether there are any differences to the given responses in terms of school counselors' proffesional experience, we conducted a Chi square analysis. Results showed that school counselors who have proffesional experience less than five years partcipate less in the following items; "substance addiction is not a problem in Turkey", "addictive substances keep people away from their problems", "nothing happens when you use a substance once" and "it is not possible to treat the addict". Moreover, school counselors who have proffesional experience between 6 to 10 years participate more in the items; "I know what kind of talk I should have with the parent of a drug addicted student", "I know how to approach a substance addicted student", "I know the steps to follow when I face a substance addict student", "my knowledge of substance addiction is adequate", "I can talk to parents about their addicted children", "I can work with students on smoking addiction", "I can identify a drug addicted student", "I can make individual psychological counseling with a substance addict student", "I can work with students on alcohol addiction", and "I can work with students experiencing drug addiction problems". 
Çetinkaya Yıldız, E. (2020). Okul psikolojik danıșmanlarının madde bağımlılığı konusundaki görüș, bilgi ve yeterlikleri. Journal of Human Sciences, 17(2), 609-631. doi:10.14687/jhs.v17i2.5926

\section{Conclusion}

This study provides important information about opinions, knowledge, and competencies of school counselors regarding substance addiction in schools. The findings obtained from the study may contribute to the literature in terms of revealing the real needs of school counselors who have received various training on substance addiction from different sources. First, the opinions of the school counselors about substance addiction were examined. The first subject that participants reached to a consensus was about substance addiction's being a problem in Turkey. Although media sometimes report that, compared to the level of seriousness in other countries, substance addiction in Turkey is not a serious problem. School counselors who work with young people responded that substance addiction is a serious problem. This finding of the study is parallel to the findings of previous studies (Özmen \& Kubanç, 2013; Ulusoy, 2017) and emphasizes that it is important to strengthen school counselors' knowledge on substance addiction. Moreover, about one third of the participants stated that they did not like addicts and about one quarter stated that they did not feel comfortable working on addiction. There are similar findings in the literature that indicate health care professionals have negative beliefs about addicts (Maslach, Jackson, \& Leither, 1997; Polonsky, Azbel, Wickersham, Taxman, Grishaev, Dvoryak, \& Altice, 2015; Sleeper and Boschain, 2013). In addition, it has been stated that the opinions of mental health professionals about addiction affect the quality of the services they provide (Lev-Ran et al., 2013; Tracy et al., 2009). For example, VailSmith, Knight, and White (1995) conducted a research study with elementary school students whose parents were addicts, and they emphasized that the services of school counselors who have their own personal experiences related to substance addiction may be affected. Therefore, it was suggested that school counselors should work on the subject themselves before providing services related to drug addiction. This finding also revealed that school counselors need information on identifying addictive substances and they need more information about substances. The study indicated that the participants did not find their knowledge about substance addiction sufficient enough. This conclusion is similar to that of other studies which revealed that school counselors (Vail-Smith, Knight, \& White, 1995) and social workers (Giannetti, Sieppert, \& Holosko, 2002) may lack knowledge about addiction. It is important to note that some school counselors may have perceived their existing knowledge to be deficient because they had not received the any education about addiction during their undergraduate program. Additionally, they might have considered their knowledge inadequate due to physiological and medical dimensions of addiction. Considering this, school counselors who provide services to young people with addiction problems, to families of addicted young people, and to children of addicted parents, it is of great importance for them to update their knowledge about newly emerging addictive substances and their possible effects.

Finally, when examining the participants' responses to their competence in conducting studies on substance addiction, it was found out that school counselors had higher competence in conducting prevention studies about addiction and cigarette addiction, and they had lower competence in conducting studies on alcohol and substance addiction. Given that school counselors carry out more preventive studies (i.e. seminars on addiction) in schools, it is expected that they see themselves as more competent in preventive studies. It can also be explained by the fact that school counselors often refer the students who have addiction problems to other experts because they feel incapable of offering necessary care due to time shortages at school. Other studies from the literature also indicated that school counselors prefer to refer addicted students other proffesionals due to shortage of time (Burrow-Sanchez \& Hawken, 2007; Burrow-Sanchez \& Lopez, 2009). In fact, this may result in a vicious cycle. Even though school counselors have undergone various education programs, they refer addicted students to other professionals due to time limitations or other reasons, and this prevents them from gaining experience. Thus, they cannot improve their competencies in helping young adults with substance addictions and therefore continue to consider themselves inadequate. As a result, it may be even more difficult for young people to receive proper health care services regarding addiction counseling. Because mental health specialists at hospitals are already very busy to devote enough time to addiction counseling. 
The study also investigated whether the school counselors' opinions on substance addiction change according to their proffesional experience. Results revealed that, the awareness levels of young school counselors' is higher than other two groups. This finding can be interpreted as a positive reflection of the studies and campaigns that have been carried out extensively in schools and media in the recent years. School counselors with professional experience between six to ten years have reported significantly higher levels of knowledge and competence in some items than school counselors with fewer and more proffesional experience. This finding can be explained by the difficulties experienced by school counselors who have just started the profession. These challenges may include anxiety, perfectionism, coping with uncertainty, and struggling to determine their roles and expectations as a school counselor (Corey, 2008). On the other hand, it is surprising that experienced school counselors who have worked ten years or more in the profession perceived their knowledge of substance addiction and their competence in carrying out studies on drug addiction as insufficient. This finding may be explained by the fact that school counselors with 11 or more years of proffesional experience think that it has been years since their graduation from university and that their field knowledge has become obsolete or that they experience professional burnout (Bardhoshi, Schweinle, \& Duncan, 2014). However, more studies are needed to establish indisputable conclusions about proffesional experience. These insecurities may be explained by the fact that the standards related to addiction counseling are not available in undergraduate and graduate programs that are providing mental health education. Underlining this, Sales (1999) stated that all psychological counselors, regardless of their field of expertise or institution, will encounter clients with direct or indirect problems related to substance addiction, but that psychological counselor education does not cover the necessary knowledge and skills. A significant part of the participants stated that they gained knowledge about substance addiction during TUBIM education, or as a result of their own individual research, but not during their undergraduate education. This weakness of education programs have been addressed in many other countries after going through similar processes. For instance, in the United States, the standards of practice of addiction counseling were established long ago, but education standards were not established until recently. Since the beginning of the 2000s, researchers have expressed their need for addiction counseling standards and emphasized the necessity for all psychological counselors to receive an education that meets the addiction counseling standards regardless of their specialization areas (Hagedorn, 2007; Salyers, Ritchie, Cocrane, \& Roseman, 2006; Whittinghill, Carroll, \& Morgan, 2004; Whittinghill, 2006). The Council for Accreditation of Counseling and Related Educational Programs (CACREP) first published training standards on addiction counseling in 2012. Hagedorn, Culbert, and Cashwell (2012) discussed the needs of CACREP's accreditation of addiction counseling and what they should include in detail. These further strengthened the psychological counseling profession. In Turkey, due to the absence of a mental health law and accreditation studies, addiction counseling can only be implemented by a small group and addiction counseling master programs still accept few students. Unfortunately, addiction counseling courses couldn't be incorporated into education programs of other methal health proffesions.

In conclusion, results revealed that it is necessary to make arrangements that addresses the needs of school counselors, and define their roles in substance addiction more clearly while strengthening them in the areas that they needed. In addition, the development of elective and flexible education programs can be suggested to those who prepare substance addiction education programs for school counselors. Moreover, it is advisable to plan the education programs in a theoretical and practical manner to provide supervision support for a certain period of time while school counselors are working with students with addictions. Additionally, to carry out future studies on substance addiction in schools in a healthier way, the adoption of the mental health law and determination of the professional standards are necessary. Finally, in order to get a proffessional service, non-field professionals should not be assigned to school counseling positions. 